\title{
Species-Specific in vitro and in vivo Evaluation of Toxicity of Silver Nanoparticles Stabilized with Gum Arabic Protein
}

This article was published in the following Dove Press journal: International Journal of Nanomedicine

\author{
Joana S Maziero' \\ Velaphi C Thipe (D) ${ }^{1,2}$ \\ Sizue O Rogero $\mathbb{D}^{1}$ \\ Adriana K Cavalcante' \\ Kelme C Damasceno' \\ Matheus B Ormenio (D) \\ Gisela A Martini' \\ Jorge GS Batista $\mathbb{D}^{3}$ \\ William Viveiros ${ }^{4}$ \\ Kavita K Katti ${ }^{2}$ \\ Alice Raphael Karikachery ${ }^{2}$ \\ DarshaKumar Dhurvas \\ Mohandoss ${ }^{5}$ \\ Rashmi DarshaKumar Dhurvas ${ }^{5}$ \\ Mohanavelu Nappinnai ${ }^{5}$ \\ José R Rogero ${ }^{3}$ \\ Ademar B Lugão' \\ Kattesh V Katti $\mathbb{D D}^{2}$ \\ 'Laboratório de Ecotoxicologia, Centro de \\ Química e Meio Ambiente, Instituto de Pesquisas \\ Energéticas e Nucleares (IPEN), Comissão \\ Nacional de Energia Nuclear- IPEN/CNEN-SP, São \\ Paulo, SP, Brazil; ' Institute of Green \\ Nanotechnology, Department of Radiology, \\ University of Missouri Columbia, Columbia, MO, \\ USA; ${ }^{3}$ Laboratório de Biomateriais Poliméricos \\ e Nanotheranóstica, Centro de Química e Meio \\ Ambiente, Instituto de Pesquisas Energéticas \\ e Nucleares (IPEN), Comissão Nacional de Energia \\ Nuclear- IPEN/CNEN-SP, São Paulo, SP, Brazil, \\ ${ }^{4}$ Laboratório de Ecotoxicologia, Companhia \\ Ambiental do Estado de São Paulo (CETESB), São \\ Paulo, SP, Brazil; ${ }^{5}$ Dhanvantari Nano Ayushadi Pvt \\ Ltd, Chennai, Tamil Nadu, India
}

Correspondence: Kattesh V Katti;

Ademar B Lugão

Email kattik@health.missouri.edu;

ablugao@gmail.com
Introduction: We report, herein, in vitro, and in vivo toxicity evaluation of silver nanoparticles stabilized with gum arabic protein (AgNP-GP) in Daphnia similis, Danio rerio embryos and in Sprague Dawley rats.

Purpose: The objective of this investigation was to evaluate in vitro and in vivo toxicity of silver nanoparticles stabilized with gum arabic protein (AgNP-GP), in multispecies due to the recognition that toxicity evaluations beyond a single species reflect the environmental realism. In the present study, AgNP-GP was synthesized through the reduction of silver salt using the tri-alanine-phosphine peptide (commonly referred to as "Katti Peptide") and stabilized using gum arabic protein.

Methods: In vitro cytotoxicity tests were performed according to ISO 10993-5 protocols to assess cytotoxicity index $\left(\mathrm{IC}_{50}\right)$ values. Acute ecotoxicity $\left(\mathrm{EC}_{50}\right)$ studies were performed using Daphnia similis, according to the ABNT NBR 15088 protocols. In vivo toxicity also included evaluation of acute embryotoxicity using Danio rerio (zebrafish) embryos following the OECD No. 236 guidelines. We also used Sprague Dawley rats to assess the toxicity of AgNP-GP in doses from 2.5 to $10.0 \mathrm{mg} \mathrm{kg}^{-1}$ body weight.

Results: AgNP-GP nanoparticles were characterized through UV (405 nm), core size $(20 \pm 5 \mathrm{~nm}$ through TEM), hydrodynamic size $(70-80 \mathrm{~nm})$, Zeta $(\zeta)$ potential $(-26 \mathrm{mV})$ using DLS and Powder X ray diffraction (PXRD) and EDS. PXRD showed pattern consistent with the $\mathrm{Ag}\left(\begin{array}{lll}1 & 1 & 1\end{array}\right)$ peak. $\mathrm{EC}_{50}$ in Daphnia similis was $4.40(3.59-5.40) \mu \mathrm{g} \mathrm{L}^{-1}$. In the zebrafish species, $\mathrm{LC}_{50}$ was $177 \mu \mathrm{g} \mathrm{L}^{-1}$. Oral administration of AgNP-GP in Sprague Dawley rats for a period of 28 days revealed no adverse effects in doses of up to $10.0 \mathrm{mg} \mathrm{kg}^{-1}$ b.w. in both male and female animals. Conclusion: The non-toxicity of AgNP-GP in rats offers a myriad of applications of AgNPGP in health and hygiene for use as antibiotics, antimicrobial and antifungal agents.

Keywords: nanoparticles, zebrafish, cytotoxicity, ecotoxicity, Daphnia similis, Sprague Dawley

\section{Introduction}

Nanotechnology provides a myriad of opportunities for the development of materials from one to 100 on the nanometers scale. ${ }^{1-13}$ Among the wide spectrum of nanomaterials in current use, silver nanoparticles (AgNPs), have gained considerable prominence attributed by their excellent physiochemical properties such as antimicrobial activity, good conductivity, and high catalytic activities. ${ }^{14-19}$ The use of AgNPs in healthcare have found applications in treating infections, preventing bacterial and fungal colonization on denture surfaces, decontamination of catheters 
and dental materials. ${ }^{20-25}$ Due to the rapidly evolving applications of AgNPs, it is imperative to understand the species-specific toxicity of AgNPs so that specific applications of functionalized AgNPs can be targeted with mini$\mathrm{mal} / \mathrm{no}$ negative impacts on our environment. ${ }^{26-28}$

The in vivo ecotoxicological tests of silver nanoparticles using representative organisms of the water column or sediments are important steps in the overall environmental toxicity evaluation of nanomaterials. ${ }^{29}$ Information on toxicity of new water purification agents are vital because we want to minimize negative impact on important aquatic organisms which are inherently important for our environment. In addition, such investigations allow estimation of permissible limits of various chemical/nanomaterial substances to protect aquatic life. ${ }^{29-31}$ Daphnia similis, fed by filtration of organic particulate material, is a planktonic microcrustacean which acts as a primary consumer in the aquatic food chain. They are also considered important indicators of water quality and, are therefore, used in studies to assess toxicity by evaluating their reproduction rates and morphological alterations. ${ }^{30-42}$

Danio rerio, also known as zebrafish, is a tropical fish species. They act as secondary consumers in the aquatic food chain. ${ }^{32-34,42}$ Zebrafish presents attractive features in toxicity evaluations of nanoparticles and experimental drugs because of its robust and social nature, rapid growth rates, high reproducibility, transparent embryos, and an established genome. $^{26,43}$ The rapid expansion of nanotechnology, with applications in electronics, health, hygiene and allied fields, has heightened the need to understand toxicological effects of various nanoparticulate-embedded finished products. ${ }^{44}$ In addition to toxicological investigations in Daphnia similis and zebrafish, evaluation of toxicological effects, if any, of silver nanoparticles in Sprague Dawley rats will provide important insights on multi-species toxicology behavior of nanomaterials. Detailed investigations including biochemical, hematological, and histopathological examinations according to the OECD guidelines, are therefore, imperative in gaining information on acute and sub-chronic toxicities post administration of silver nanoparticles.

In our detailed toxicity studies of AgNP-GP, we have, therefore, chosen the following organisms and animals: 1) Daphnia similis for the acute ecotoxicity tests; 2) Danio rerio for the evaluation of acute embryotoxicity tests; and 3) Sprague Dawley rats for toxicity behavioral investigations. Such investigations would provide insights on systemic toxicity and thus help in defining toxicity limits for various drug-related applications. ${ }^{43,45,46}$ Multispecies toxicity testing recognizes the importance of community conditioning where ecological structures are historical, nonequilibrial, and by default highly complex. Given the complex nature of ecological structures, our investigations, using multispecies for toxicity tests of AgNP-GP, unequivocally provides the fundamental understanding in terms of design criteria for multispecies toxicity tests, data analysis, interpretation, and the overall toxicity evaluation. In particular, zebrafish have become excellent animal models for evaluations of in vivo toxicity of experimental drugs and nanoparticles because they: 1) exhibit significant homology (genetic and organ system) with the human genome; 2) possess immense fecundity; 3 ) ability for external fertilization reproduction; 4) ease of genetic modification; and 5) show transparency through early adulthood development, thus providing opportunities for sophisticated utilization for timelapse imaging modalities to monitor biological and disease processes, in addition to signaling pathways. ${ }^{47-49}$ Therefore, our multispecies in vivo toxicity investigations, as outlined in this paper, provide important insights on species-specific toxicity of AgNPs and thus opens up extensive applications of AgNPs utilization as building blocks for next generation antibiotic, antimicrobial and antifungal agents' development.

\section{Materials, Methods and Instrumentation}

The AgNP-GP was produced using a slightly modified procedure as reported by us in the patent No. US 9,005,663 B2 ${ }^{50}$ and as supplied by Dhanvantari Nano Ayushadi (DNA) Private Limited, Chennai, India. Silver nitrate and gum arabic used in the production of silver nanoparticles were purchased from Sigma-Aldrich (St. Louis, MO, USA). Trimeric phosphine L-alanine amino acid conjugate (referred to as or Katti Peptide (KPA)) was used as a reductant for the synthesis of silver nanoparticles from silver nitrate $\left(\mathrm{AgNO}_{3}\right)$ as shown in Figure $1 .^{51-54}$ We have procured natural rubber latex (NRL) extracted from Hevea brasiliensis.

The molecular absorption spectra of the AgNP-GP was measured on a Spectramax i3 (Molecular Devices, USA) spectrophotometer in the wavelength range between 230 and $900 \mathrm{~nm}$ using an optical path quartz cuvette of $10 \mathrm{~mm}$. This research was carried out at the Polymeric and Nanotechnical Biomaterials Laboratory of the Nuclear and Energy Research Institute (IPEN), São Paulo, Brasil, as well as at the Institute of Green Nanotechnology, University of Missouri, Columbia, MO, USA.

Size of AgNP-GP was measured by transmission electron microscopy (TEM). Sample Preparation: AgNP-GP 
sample was applied to glow-discharge $(15 \mathrm{~mA}$, negative charge for 25 seconds) using a 400-mesh copper grid covered by a thin layer of continuous carbon film (Ted Pella, Inc., USA). A negative charge of $15 \mathrm{~mA}$ was applied for 25 seconds using the Glow-discharge equipment (PELCO easiGlow ${ }^{\mathrm{TM}}$ ). After loading, $3 \mu \mathrm{L}$ of the sample was deposited. After 1 minute, filter paper was used to remove excess sample and the grid was washed 3 times with reverse osmosis water. Dynamic light scattering (DLS): Zetasizer measurements, using a Nano Series from Malvern Instruments at the Institute of Chemistry of the University of São Paulo, were performed to determine the hydrodynamic size (core size of AgNP + GP capping) and zeta potential of the AgNP-GP. In the DLS, the light scattering intensity is proportional to the particle size. The zeta potential refers to the surface charge of the nanoparticles; values far from zero guarantees stability of the colloidal suspension due to the electrostatic repulsion that occurs between the nanoparticles (Table 1).

A red-orange aqueous dispersion of stabilized nanoparticles in water was spread out on disposable glass slides and allowed to evaporate overnight under ambient conditions, yielding a transparent red-orange film. The film was scraped off the slide with a steel razor blade and pressed between two sheets of weighing paper by hand to form a pellet which was mounted on a polyimide single crystal sample loop. X-ray diffraction data was measured on a Bruker X8 Prospector (Bruker AXS, Madison, WI, USA) single crystal diffractometer using $\mathrm{Cu}-\mathrm{K} \alpha$ radiation from a microfocus source with multilayer optics $(\lambda=1.54060 \AA$, power $=45$ $\mathrm{kV}, 0.60 \mathrm{~mA}$ ). A series of 15 4-minute long photographs were taken while rotating the sample $360^{\circ}$ about the phi axis, giving a total irradiation time of 1 hour. X-ray intensities were recorded across the $2 \theta$ of $28.5^{\circ}$ to $60.5^{\circ}$ using an Apex II CCD area detector situated at a crystal-todetector distance of $10.0 \mathrm{~cm}$ and with the detector remaining stationary throughout the measurement. Photographic data were reduced by radially integrating a $33^{\circ}$-wide sector of the photograph in shells of $0.02^{\circ}$ in $2 \theta$ using the Bruker Apex3 software suite Apex3, AXScale, and SAINT, version 2017.3-0, Bruker AXS, Inc., Madison, WI, 2018. ${ }^{55}$

The high-resolution transmission electron microscopy (TEM, Thermo Fisher Tecnai F30 G2 Twin) was operated at $300 \mathrm{kV}$ on a Gatan ultra-scan CCD camera. Energy dispersive X-ray (EDS) mapping was collected in scanning TEM high angle annual dark field imaging mode using a Bruker $30 \mathrm{~mm}^{2}$ active area Silicon Drift Detector with super light element window to confirm the elemental distribution.

\section{Synthesis and Characterization of Gum Arabic Stabilized Silver Nanoparticles}

A $2 \mathrm{mg}$ sample of gum arabic was added to $6 \mathrm{~mL}$ of deionized water in a $20 \mathrm{~mL}$ vial and stirred on a preheated hot plate. When the temperature of the solution reached $100^{\circ} \mathrm{C}, 100 \mu \mathrm{L}$ of $0.1 \mathrm{M}$ silver nitrate solution was added followed by $20 \mu \mathrm{L}$ of $0.1 \mathrm{M}$ trimeric phosphine L-alanine amino acid conjugate ("Katti Peptide": KPA) solution as a reducing agent. Immediately after the addition of the KPA solution, the color of the reaction mixture turned from colorless to dark brown, indicating the formation of silver nanoparticles. Then the reaction mixture was stirred at reduced temperature for 10 minutes before heating was turned off. Stirring was continued at room temperature for another 90 minutes. Then the nanoparticles

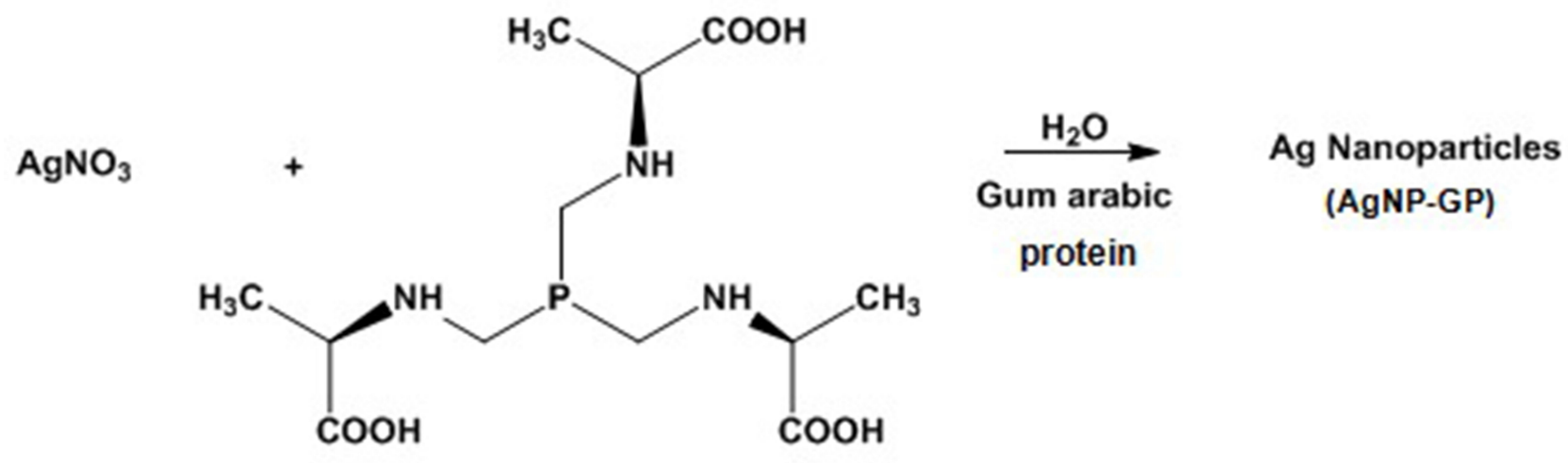

L-Alanine Katti Peptide

Figure I Synthesis of AgNP-GP through L-Alanine Katti Peptide and stabilized with gum arabic protein. Abbreviation: AgNP-GP, silver nanoparticles. 
were characterized by UV-Visible spectrophotometry, electron microscopy, powder X-ray powder diffraction analysis (PXRD) and zetasizer and zeta potential measurements. Atomic absorption spectroscopy (AAS) was used to measure Ag concentration in AgNP-GP.

\section{Cytotoxicity Index $\left(\mathrm{IC}_{50}\right)$}

The determination of AgNP-GP $\mathrm{IC}_{50}$ (cytotoxicity index is the concentration of the solution that causes injury or mortality to $50 \%$ of the exposed cells in the assay), was carried out according to the ISO 10993-5. We used the well-known neutral red uptake methods to carry out this assay. AgNP-GP solutions in specific dilutions $(6.2,12.5,25,50$ and 100\%) were incubated with NCTC clone 929 (CCIAL 020) of mouse connective tissue cells which were adhered to the 96 wells of the cell culture microplate purchased from Nucleus of Cell Culture of Adolfo Lutz Institute. These studies were done in triplicate to obtain the standard deviation. The neutral red uptake method was used to determine the cytotoxicity index of AgNP-GP to measure concentration of the test sample solution that causes mortality in $50 \%$ of the exposed cells $\left(\mathrm{IC}_{50}\right)$. The methodology, as followed, meets ISO 10993-5 standards. The NCTC clone 929 (CCIAL 020) derived from mouse connective tissue cells were grown and maintained in Minimum Eagle's Medium (MEM) using nonessential amino acids and sodium pyruvate (MEM-use), supplemented with $10 \%$ fetal bovine serum. Then, 96-well cell culture microplates were prepared containing $7 \times 10^{4}$ cells per well (supplied by the Nucleus of Cell Culture of Adolfo Lutz Institute) and were treated with $9.19 \mathrm{mg} \mathrm{L}^{-1}$ AgNP-GP in dilutions of $6.2,12.5,25,50$ and 100\%; this assay was performed in triplicate tests.

Aluminium oxide $\left(\mathrm{Al}_{2} \mathrm{O}_{3}\right)$ in culture medium $\left(0.1 \mathrm{~g} \mathrm{~mL}^{-1}\right)$, served as a negative control while natural rubber latex (NRL) extract in culture medium $\left(0.01 \mathrm{~g} \mathrm{~mL}^{-1}\right)$ served as a positive control. The culture medium was used for the cellular control.

Table I Physicochemical Characteristics of AgNP-GP

\begin{tabular}{|l|l|l|l|l|l|}
\hline \multicolumn{6}{|c|}{ Dynamic Light Scattering (DLS) and Zeta Potential } \\
\hline Sample & $\begin{array}{l}\text { UV } \\
\lambda_{\max } \\
(\mathbf{n m})\end{array}$ & $\begin{array}{l}\text { Hydrodynamic } \\
\text { Size } \varnothing(\mathbf{n m})\end{array}$ & $\begin{array}{l}\text { TEM } \\
\text { (Core } \\
\text { Size) }\end{array}$ & PDI & $\begin{array}{l}\zeta- \\
\text { Potential } \\
(\mathbf{m V})\end{array}$ \\
\hline $\begin{array}{l}\text { AgNP- } \\
\text { GP }\end{array}$ & 405 & $70-80$ & $20 \pm 5$ & 0.37 & -26 \\
\hline
\end{tabular}

Abbreviations: AgNP-GP, silver nanoparticles stabilized with gum arabic protein; PDI, polydispersity index; TEM, transmission electron microscopy; UV, ultraviolet spectroscopy; $\zeta$, zeta.
Neutral red incorporations, in both living and intact cells, were used as indicators of cell viability. The optical density measurements of final test solutions (on a spectrophotometer ELISA reader-SUNRISE from TECAN) were performed at $540 \mathrm{~nm}$ using $600 \mathrm{~nm}$ as a reference filter. We used standard software, installed in the spectrophotometer, to calculate statistically significant percentages of cell viability while Origin 8.0 software was used for obtaining the $\mathrm{IC}_{50}$ values

\section{Measurements of Acute Ecotoxicity Using Daphnia similis}

The acute ecotoxicity tests were performed based on the ABNT NBR 15088 (2011) standard, to determine the effective concentration $\left(\mathrm{EC}_{50}\right)$ of AgNP-GP that causes immobility to $50 \%$ of the exposed organisms. The organisms were grown and maintained in the Ecotoxicology Laboratory of Nuclear and Energy Research Institute (IPEN), according to the ABNT NBR 15088 (2011) standard. Organisms were fed an algal suspension of Pseudokirchneriella subcapitata $\left(10^{5}\right.$ cells $\mathrm{mL}^{-1}$ ) and a mixture of yeast and fish chow, and maintained in Murashige and Skoog (MS) medium under controlled conditions: temperature $\left(20 \pm 2^{\circ} \mathrm{C}\right)$ and light-dark cycles (12:12 hours). ${ }^{56}$

Neonates from 6 to 24 hours were exposed to various concentrations $\left(1 ; 2 ; 4 ; 8\right.$ and $\left.16 \mu \mathrm{g} \mathrm{L}^{-1}\right)$ of AgNP-GP for 48 hours, 20 organisms distributed in 4 tubes per concentration. A stock solution of $100 \mu \mathrm{g} \mathrm{L}^{-1}$ AgNP-GP was used. Murashige and Skoog medium (MS medium) was used as the control. For gum arabic protein (GP) control, $0.4 \mathrm{~g}$ of the sample was used in $200 \mathrm{~mL}$ of MS medium. ${ }^{57}$ An immobile organism is understood as one that is unable to swim in the water column after a slight agitation of the container. Immobility of each organism was used as a well-accepted standard for the determination of acute toxicity according to ABNT NBR 10588 protocol. At the end of each assay, Trimmed Spearman-Karber software was used to determine the $\mathrm{EC}_{50}$ based on the number of immobile organisms as a function of concentration. ${ }^{58}$

\section{Acute Embryotoxicity Assay with Danio rerio (Zebrafish)}

Determination of the lethal concentration $\left(\mathrm{LC}_{50}\right)$ of AgNPGP that causes mortality to $50 \%$ of the exposed organisms were carried out using assay methods based on the OECD 236 (Guideline on Fish Embryo Toxicity Test - FET, 2013) guidelines. ${ }^{59}$ Based on preliminary experiments, it was detected that the highest concentration of AgNP-GP 
that caused $100 \%$ mortality of organisms was $1250 \mu \mathrm{g} \mathrm{L} \mathrm{L}^{-1}$. Based on these results, systematic experiments for $\mathrm{LC}_{50}$ evaluation on zebrafish embryos were performed. The use of zebrafish embryos in the present study was authorized by the Ethics Committee on the Use of Animals (CEUA/ IPEN) opinion $n^{\circ} 174 / 16 /$ CEUA-IPEN/SP under the coordination of the Biotechnology Center (CB), of the Energy and Nuclear Research Institute (IPEN/CNEN-SP).

These studies were carried out at the Laboratory of Ecotoxicology located at the Environmental Company of the State of São Paulo (CETESB). Adult males and females were maintained separately under controlled temperature ( 25 $\pm 2^{\circ} \mathrm{C}$ ), light and dark cycle. They were fed twice daily with fish feed and Artemia spp. We used breeders between 6 and 24 months of age, ${ }^{56}$ which were housed in small aquaria, maintaining a ratio of two males to one female. Immediately after spawning, we collected the eggs from the aquaria to transport them to the Ecotoxicology Laboratory at IPEN. We used the standard $(\geq 80 \%)$ as the validation criteria for fertilization rate and the organisms were utilized with development stage of up to 4 hours post fertilization (hpf). The authenticity of our data was established by using zinc chloride $\left(\mathrm{ZnCl}_{2}\right)$ for testing organism sensitivity.

We seeded one egg per well with $2 \mathrm{~mL}$ of test solution in a 24-well plate. MS media was diluted with distilled water. We prepared the GP control, using $0.4 \mathrm{~g}$ of GP per $200 \mathrm{~mL}$ of MS media solution. Zinc chloride $\left(\mathrm{ZnCl}_{2}\right)\left(100 \mathrm{mg} \mathrm{L} \mathrm{L}^{-1}\right.$ concentration) was used as a reference substance for positive control. The assay plates were incubated at $26^{\circ} \mathrm{C}$ for 96 hours and an inverted microscope was used to observe the organisms every 24 hours. Monitoring of the embryonic phase was performed through observations of parameters including coagulation of fertilized eggs, heartbeats, pigmentation of the eyes and the overall body. We also looked for changes in the formation of somite, tail detachment, hatching, and the overall lethality. The AgNP-GP concentrations used in our experiments were as follows: 78; 156; 313; 625 and 1250 $\mu \mathrm{g} \mathrm{L}^{-1}$. Post exposure periods, the final $\mathrm{LC}_{50}$ was calculated based on the number of dead organisms as a function of AgNP-GP concentrations. The $\mathrm{LC}_{50}$ calculation was performed using the Trimmed Spearman-Karber software. ${ }^{58}$

\section{Determination of the No Observed Adverse Effect Level (NOAEL) Assay}

The NOAEL was determined by repeated dose (28 days) toxicity assay by oral route in Sprague Dawley rats. This assay was conducted at the Centre for Toxicology and
Development Research, a unit of Sri Ramachandra Institute of Higher Education and Research (India), an internationally renowned GLP certified facility (GLP/C-105/2017). This investigation was inspected, audited and approved by the ethics committee in accordance with the study plan, and standard operating procedures. Schedule " $Y$ " requirements and guidelines were followed for permission to import and/or manufacture new drugs for sale or to undertake clinical trials. All approvals were based on Drugs and Cosmetic (Second Amendment) Rules, Ministry of Health and Family Welfare, Government of India, 2005 and OECD Series on Principles of Good Laboratory Practice and Compliance Monitoring, Number 1, ENV/MC/CHEM (98) 17. The animal protocol was fully approved by the institutional ethics committee board. 24 male and 24 female Sprague Dawley rats were used for the study. Study design consisting of four groups [Vehicle control (G1), Low dose (G2), Mid dose (G3), High dose (G4)], each had six animals in each sex per group. Animals of G1 received water, G2 received test item dose $5 \mathrm{mg} \mathrm{kg}^{-1}$ body weight, $\mathrm{G} 3$ received test item dose $7.5 \mathrm{mg}$ $\mathrm{kg}^{-1}$ body weight and $\mathrm{G} 4$ received test item undiluted dose of volume $10 \mathrm{mg} \mathrm{kg}^{-1}$ body weight. The doses of respective groups were administered orally once a day for 28 days and the following parameters were investigated:

\section{Mortality and Morbidity}

Animals from all groups were observed for mortality and morbidity twice daily from acclimatization and up to the day of necropsy.

\section{Clinical Signs of Toxicity}

General clinical observations of animals of all groups were performed once daily after the last dosing performed from day 1 till the day of necropsy. Detailed clinical examination was performed prior to first dosing and thereafter before the day of necropsy.

\section{Body Weights and Body Weight Changes}

Individual body weights of all animals from all groups were recorded on day 0 of acclimatization, once before first dosing (day 0 ), thereafter once weekly and a day prior to necropsy. The body weight changes were calculated and reported.

\section{Feed Consumption}

Feed consumption of animals was recorded daily from the day of dosing (day 0), till the day of necropsy, except on the day of overnight fasting. The average feed consumption was calculated and reported. 


\section{Urine}

Specific gravity, microalbumin, bilirubin, urobilinogen, ketone protein, glucose, epithelial cells, cast crystals, occult blood and microscopic examination of urine sediments, were measured.

\section{Haematology}

Measurements included: total leucocytes count, differential leucocyte counts (eg, neutrophil; lymphocytes; monocytes; eosinophil and basophil). Measurements also included: total erythrocyte count, hemoglobins, hematocrit for measuring the proportion of red blood cells in the blood. Hematology measurements also included platelet count and terminal bone marrow examinations.

\section{Biochemical Parameters}

Measurements included: cholesterol; triglycerides; blood urea; nitrogen (calculated from urea) and creatinine. Total protein estimations included: albumin; globulin (calculated value from total protein and albumin). Estimations also included: aspartate; transaminase; alanine; alkaline phosphatase; total bilirubin; phosphorus; potassium; sodium and total calcium.

\section{Organ Weights and Gross Pathology}

All surviving animals were necropsied on day 28, using $\mathrm{CO}_{2}$ euthanasia and were subjected to detailed gross necropsy which included gross examination of external orifices, the cranial, thoracic, abdominal cavities and their contents and organs as listed below. On completion of the gross pathology examination, the tissues and organs noted below were collected and weighed from all animals. Collected organs (excluding eyes and testes) were preserved in 10\% Neutral Buffered Formalin (NBF) solution. Eyes and testes were preserved in Davidson and Modified Davidson's fixative.

\section{Histopathology}

Parameters for histopathology included: skin (with mammary gland for females); lymph node; mesenteric salivary glands; eyes; brain (cerebrum, cerebellum, and mid brain medulla pons); pituitary trachea; esophagus; thyroid; parathyroid; thymus; heart; lungs (perfused with 10\% NBF before fixation); stomach, small and large intestines (with Peyer's patches, perfused with $10 \%$ NBF before fixation); pancreas, liver, adrenals, kidneys, urinary bladder (perfused with $10 \%$ NBF before fixation) gonads: male-epididymis, male sex glands as whole and testes gonads: female-ovaries, uterus with cervix, and skeletal muscle spinal cord (at three levels: cervical, mid-thoracic und lumbar).

\section{Statistical Analysis}

We have used the following well-established standards to achieve statistical significance of our experimental data: Wherever possible/applicable, we have performed triplicate sets of experiments. Cytotoxicity assay: Origin 8.0 software was used to obtain the percentage of cell viability and the $\mathrm{IC}_{50}$. Acute ecotoxicity test: To determine the $\mathrm{EC}_{50}$, the Trimmed Spearman-Karber software was used to calculate the immobile organisms. Acute embryotoxicity assay: To determine the $\mathrm{LC}_{50}$, the Trimmed Spearman-Karber software was used to calculate the lethality of organisms; and the rates of morphological changes observed in the organisms during the tests were evaluated by Student's $t$-test, with a significance level of $p<0.05$.

\section{Results}

\section{Synthesis and Characterization of Gum} Arabic Protein Stabilized Silver Nanoparticles (AgNP-GP) Using

\section{L-Alanine Katti Peptide (KPA)}

L-Alanine Katti Peptide (KPA) is an effective nanoparticle formation agent and reduces gold and silver salts to form the corresponding nanoparticles in consistent size and great stability. ${ }^{4,50,53,54,60-79}$ The production of silver nanoparticles using KPA which proceeds in an aqueous environment, as shown in Figure 1, does not require any harsh chemicals or generate any harmful by-products and is therefore an environmentally-benign green nanotechnology process. The Katti Peptide (KPA) is a very effective reducing agent for the synthesis of silver nanoparticles (Figure 1) ${ }^{34}$ Both the amino acid and phosphine portions in KPA serve as reducing agents to transform silver (I) nitrate into metallic silver nanoparticles in aqueous phase. Consequently, the Katti Peptide undergoes oxidation while gum arabic, consisting of glycoproteins and polysaccharides, stabilizes the silver nanoparticles. Nuclear magnetic resonance (NMR) investigation of the nanoparticle synthesis clearly shows quantitative utilization of the trimeric phosphine amino acid conjugate (KPA). ${ }^{31} \mathrm{P}$ NMR investigations have shown complete dissociation of KPA, in a redox process in its reaction with silver (I) nitrate, into phosphoric acid as the only biocompatible byproduct (Figure 1). The silver content in AgNP-GP was found to be $170 \mathrm{ppm}$ as established through atomic absorption spectroscopy (AAS). 
The UV-Visible absorption spectrum showed the respective peak at $405 \mathrm{~nm}$ (Figure 2), thus confirming the formation of AgNPs. Additional characterization of AgNP-GP has been carried out using transmission electron microscopy (TEM). The TEM images of AgNP-GP, as shown in Figure 3, confirm particulate sizes in the range $20 \pm 5 \mathrm{~nm}$. Powder X ray diffraction (PXRD) showed peaks consistent with the $\mathrm{Ag}\left(\begin{array}{lll}1 & 1 & 1\end{array}\right)$ pattern for Ag metal (Figure 4A). ${ }^{55}$ We have further confirmed the formation of silver nanoparticles through X-ray energy dispersive spectroscopic (EDS) analysis of AgNP-GP (Figure 4B). The insert image, as shown in Figure 4B corresponds to the $\mathrm{Ag}$ elemental mapping confirming that AgNP-GP particles are made up of $\mathrm{Ag}$ in combination of the HRTEM image of the particle where the EDS map was done. Full details of the physicochemical parameters which include core and hydrodynamic sizes of AgNP-GP are outlined in Table 1.

\section{Cytotoxicity Assay}

The cell viability results in relation to the AgNP-GP concentrations were plotted and are depicted in Figure 5. The intersection between the cell viability curve and the $50 \%$ viability line in these graphs gave the $\mathrm{IC}_{50}$ values. The $\mathrm{IC}_{50}$ value obtained was $2.57 \mathrm{mg} \mathrm{L}^{-1}$ since dilutions were made from the initial concentrations of $9.19 \mathrm{mg} \mathrm{L}^{-1}$.

\section{Acute Ecotoxicity Assay Using Daphnia similis}

The results of AgNP-GP acute ecotoxicity on Daphnia similis, as shown in Figure 6, indicated that there was an increase in immobility of the organisms with increasing AgNP-GP concentrations. It may be noted that the MS Medium and GP controls showed no immobility. Full details of $\mathrm{EC}_{50}$ values, as shown in Table 2, indicated that the mean $\mathrm{EC}_{50}$ of AgNP-GP was $4.40(3.59-5.40) \mu \mathrm{g} \mathrm{L}^{-1}$ as confirmed through triplicate sets of measurements.

\section{Acute Embryotoxicity Assays Using Danio rerio}

In the positive control, the exposed embryos showed $100 \%$ of coagulation. The MS Medium and GP controls showed no mortality. The results of acute embryotoxicity of AgNP-GP in Danio rerio, as depicted in Figure 7, provide conclusive evidence on the sensitivity and lethality of the organism toward increasing concentrations of AgNP-GP. The results of embryotoxicity assays are shown in Table 3 . The mean value of AgNP-GP $\mathrm{LC}_{50}$ was found to be $177 \mu \mathrm{g} \mathrm{L}^{-1}$ as established through triplicate measurements.

Effects of exposing Danio rerio to various concentrations of AgNP-GP over a period of 96 hours are summarized in Figure 8. These images revealed that Danio rerio undergo noticeable morphological changes including reduction in head size, reduced body size, significant changes in spinal curvature, as well as changes in cardiac and/or yolk edema. Full description of these and related anatomical changes upon exposure to AgNP-GP are described in Figure 9.

\section{Determination of the No Observed Adverse Effect Level (NOAEL) Mortality, Morbidity, and Clinical Signs of Toxicity}

Our results of detailed toxicity investigations using Sprague Dawley rats have inferred that AgNP-GP did not cause any mortality or clinical signs of toxicity in any of the test animals treated with silver nanoparticles even at the maximum dosage of $10.0 \mathrm{mg} \mathrm{kg}^{-1}$ body weight. The AgNP-GP treated animal groups did not reveal any test item-related effects throughout the experimental period when compared to the control groups of the animals. These data reveal that the doses of up to $10.0 \mathrm{mg} \mathrm{kg}^{-1}$ body weight were well tolerated by the animals as shown in Table 4 . We have also analyzed effects on feed consumption. The test item did not have any noticeable effects on feed consumption of animals, in both male and female groups of AgNP-GP treated animals in comparison with control groups. Urine analysis revealed that the test item did not induce any changes in urine parameters in any of the AgNP-GP-treated animals except in the urine volume. We observed an increase in the urine volume in male animals at $7.5 \mathrm{mg} \mathrm{kg}^{-1}$ body weight (G3) and at the high dose of $10.0 \mathrm{mg} \mathrm{kg}^{-1}$ body weight (G4) when compared to the control groups (G1). Table 4 outlines the clinical signs of toxicity, mortality and morbidity from day 0 to 28 .

\section{Blood parameters and hematology}

Significant increases in reticulocyte counts was observed in the male (G2) groups administered with $5.0 \mathrm{mg} \mathrm{kg}$ body weight as compared with the control group (G1). Female animals administered with $7.5 \mathrm{mg} \mathrm{kg}^{-1}$ body weight of AgNP-GP also showed increases in reticulocyte counts of mid (G3) as compared with the control group (G1). Significant increases in reticulocyte counts were particularly pronounced in the female groups at the highest 


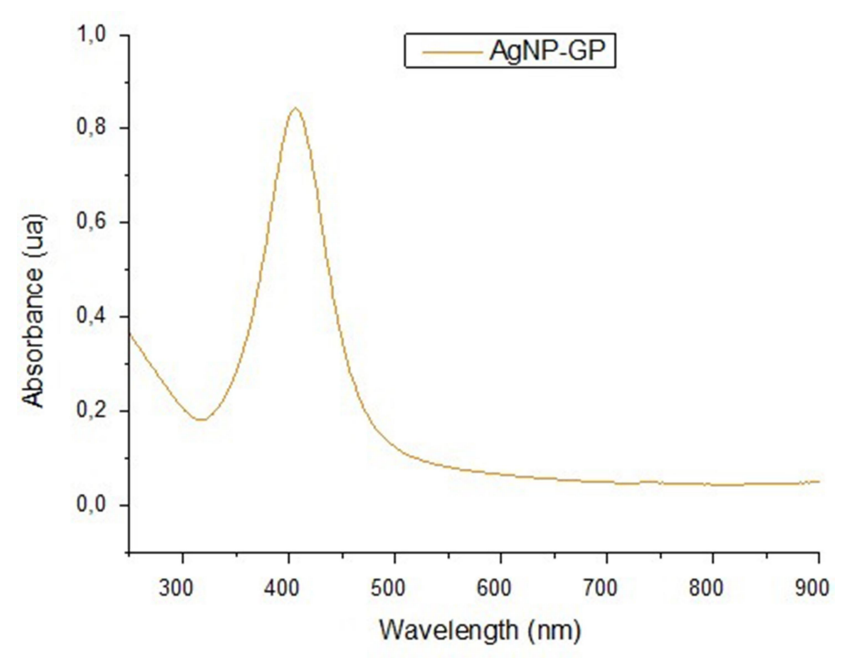

Figure 2 Ultraviolet-visible spectra of AgNP-GP with surface plasmon resonance at $405 \mathrm{~nm}$.

Abbreviation: AgNP-GP, silver nanoparticles.

dose of $10.0 \mathrm{mg} \mathrm{kg}^{-1}$ body weight (G4) as compared with the control group. We also observed a significant decrease in the levels of lymphocytes in males of the mid dose group (G3) as compared to the control group. Glucose level measurements indicated a significant increase in the male group of animals administered with $7.5 \mathrm{mg} \mathrm{kg}^{-1}$ body weight (G3) as well as $10.0 \mathrm{mg} \mathrm{kg}^{-1}$ body weight (G4) as compared to the control group. However, in female animals, significant increases in glucose levels, as compared with the control group, were observed throughout the $5.0 \mathrm{mg} \mathrm{kg}^{-1}-10.0 \mathrm{mg} \mathrm{kg}^{-1}$ body weight dosing regimen.

Measurements of urea levels indicated that AgNP-GP caused a decrease in urea levels in males at the highest dose of $10.0 \mathrm{mg} \mathrm{kg}^{-1}$ body weight (G4) as compared to the control group. Measurements of total calcium levels indicated an increase in total calcium levels in males within the G3 and G4 groups as compared with the control groups. We also observed a noticeable increase in the potassium levels in female animals administered with $10.0 \mathrm{mg} \mathrm{kg}^{-1}$ AgNP-GP of body weight (G4). It is important to recognize that administration of AgNP-GP throughout the $5.0-10.0 \mathrm{mg} \mathrm{kg}{ }^{-1}$ body weight dosing regimen caused no coagulation in any of the test-item treated groups as compared to the control group. Evaluation of absolute and relative organ weights during the course of the 28-day investigation revealed no statistically significant body/organ weight changes in all the treated male and female groups (G2-G4).

\section{Gross Pathology}

Gross pathological evaluations throughout the course of the 28-day investigation revealed no statistically significant AgNP-GP test item-related findings in all the treated male and female groups (G2-G4). Histopathological microscopic examinations throughout the course of the 28day investigation revealed no statistically significant AgNP-GP test item-related findings in any of the treated animal groups (G2-G4) when compared with the animals of the control group. Detailed toxicological findings from the treatment of AgNP-GP at the 5.0-10.0 $\mathrm{mg} \mathrm{kg}^{-1}$ body weight dosing regimen are summarized in Table 5. Based on the above results, under the in vivo toxicology testing conditions, AgNP-GP was found to be well tolerated within the $10.0 \mathrm{mg} \mathrm{kg}^{-1}$ body weight dosing range when administered orally for a period of 28 days in Sprague Dawley rats. Therefore, the NOAEL of AgNP-GP is
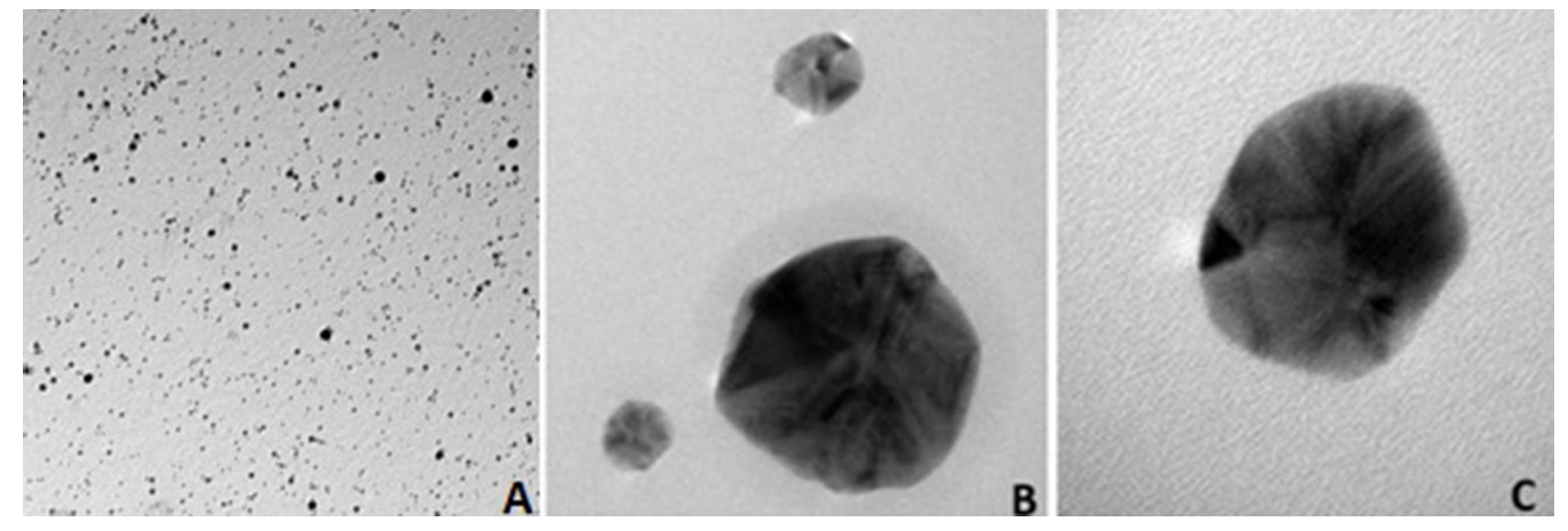

Figure 3 Transmission electron microscopic images of silver nanoparticles: (A) magnification at 29,000x (I00 nm scale); (B) magnification at 280,000x (20 nm scale); (C) magnification at $700,000 \times(10 \mathrm{~nm}$ scale) . 


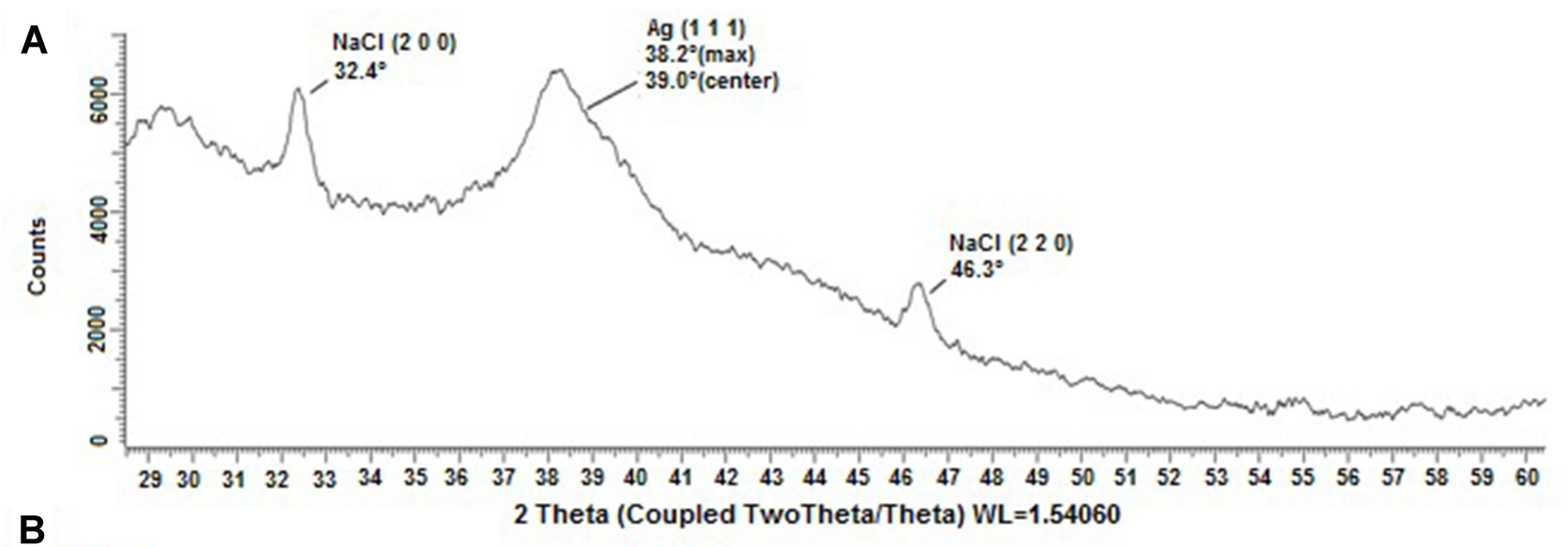

B

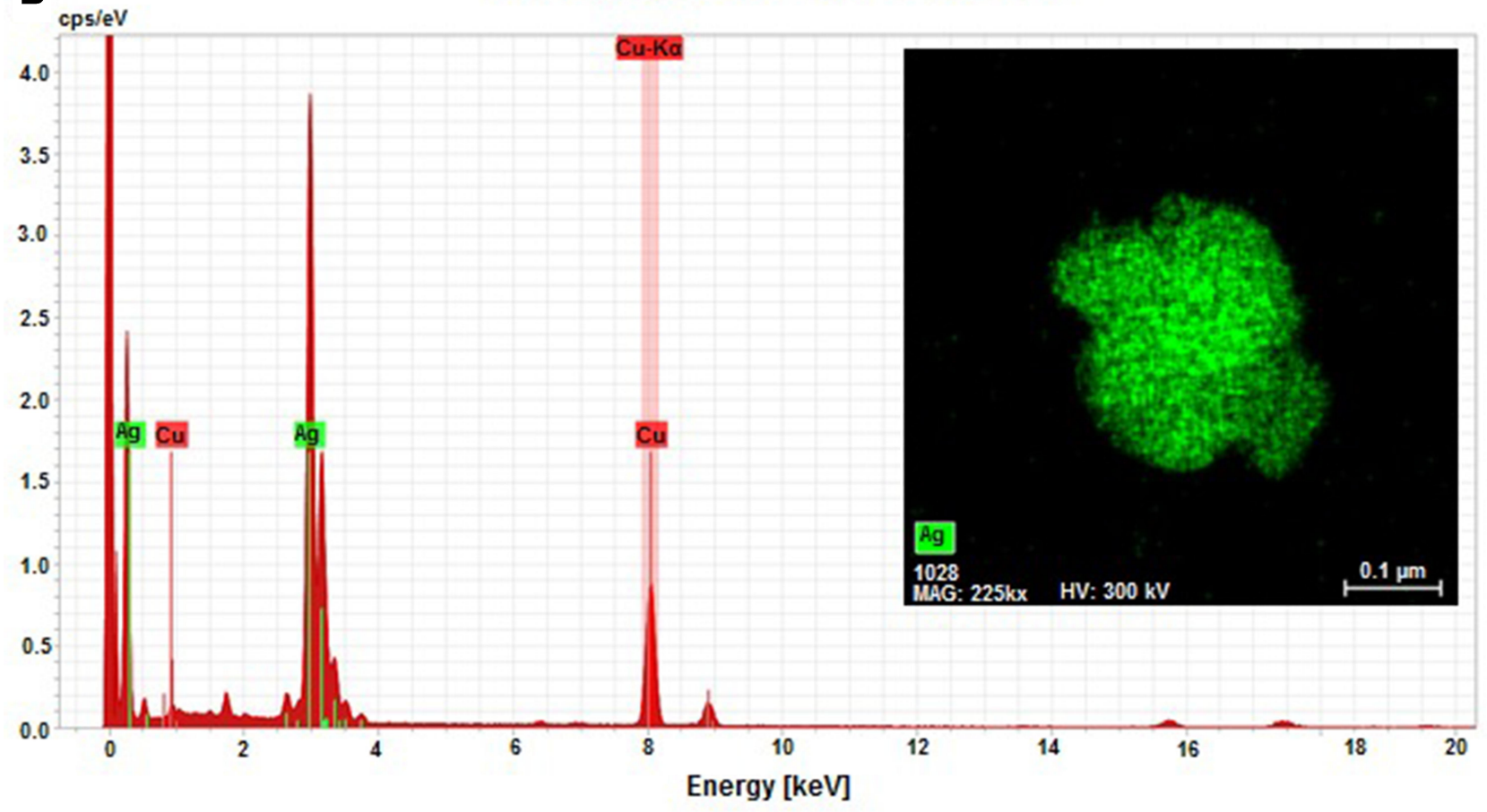

Figure 4 Powder $X$ ray diffraction (PXRD) and Energy-dispersive X-ray spectroscopy (EDS) analysis of AgNP-GP; (A) PXRD patterns of evaporated AgNP-GP residue. Figure shows the main PXRD peak for $\mathrm{Ag}$ metal and the other two peaks are for $\mathrm{NaCl}$ which is present as a contaminant on the surfaces of the glass slides and likely entered the sample during evaporation. All peaks are shifted by $+0.7-0.8^{\circ}$ from their literature values, which indicates a sample displacement error of $+0.2 \mathrm{~cm}$. The $\mathrm{NaCl}$ peaks serve as an internal standard and clearly demonstrate the significant particle size broadening of the Ag peak; (B) EDS spectra of AgNP-GP. The insert image shown corresponds to the Ag elemental mapping confirming that AgNP-GP particles are made up of $\mathrm{Ag}$ in combination of the HRTEM image of the particle where the EDS map was done. Abbreviations: AgNP-GP, silver nanoparticles; EDS, energy dispersive spectroscopy; HRTEM, high resolution transmission electron microscopy; PXRD, powder $\mathrm{X}$ ray diffraction.

$10.0 \mathrm{mg} \mathrm{kg}{ }^{-1}$ body weight in both male and female Sprague Dawley rats.

\section{Discussion}

The KPA-trimeric alanine phosphine conjugate (commonly referred to as Katti Peptide) serves as an excellent reducing agent to transform silver nitrate to well-defined silver nanoparticles stabilized with the gum arabic protein (AgNP-GP; Figure 1). ${ }^{50,53,54,74}$ Extensive research from our laboratories has provided detailed scientific rationale on the realistic potential of KPA "Katti Peptide" for the production of gold and silver nanoparticles. ${ }^{4,50,51,60-73,75-80}$ The UVVisible spectrophotometry results for the AgNP-GP sample showed the maximum absorption wavelength centered at $405 \mathrm{~nm}$, indicating the presence of AgNPs (Figure 2). ${ }^{22,81-}$ ${ }^{83}$ Particle size measurements obtained by TEM showed an average value of $20 \pm 5 \mathrm{~nm}$ (Figure 3). Zeta potential measurements indicated $-26 \mathrm{mV}$ suggesting excellent in vitro stability due to electrostatic repulsions between the silver nanoparticles, thus preventing collision and 


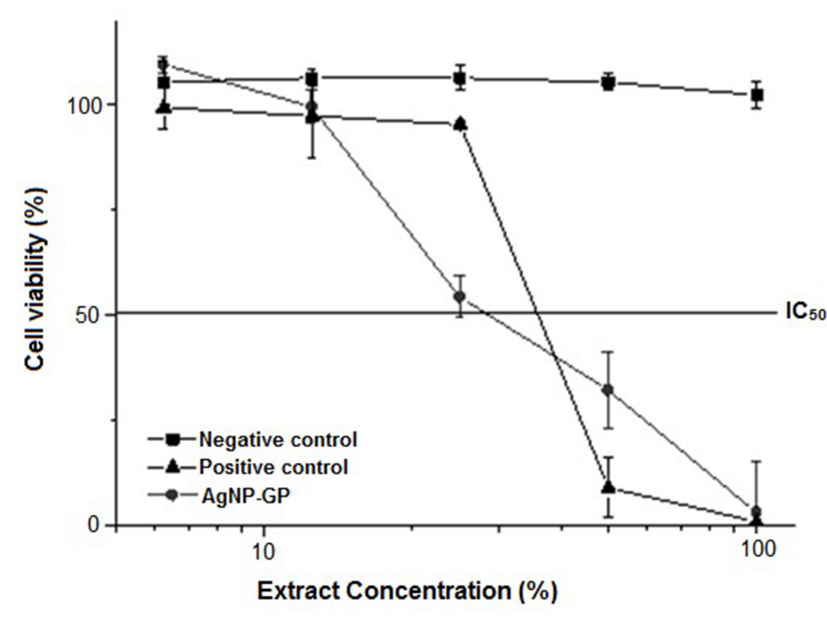

Figure 5 Cell viability curves of AgNP-GP, positive control (natural rubber latex), and negative control (an extract of aluminum oxide) as evaluated through in vitro cytotoxicity assay using the neutral red uptake method.

Abbreviations: AgNP-GP, silver nanoparticles; $\mathrm{IC}_{50}$, cytotoxicity index concentration that causes injury or mortality to $50 \%$ of the exposed cells in the assay.

aggregation of the nanoparticles. Hydrodynamic size measurements showed a size of 70-80 nm, suggesting effective encapsulation of gum arabic protein around silver nanoparticles. The silver concentration in AgNP-GP, from batch to batch preparations, showed consistently silver content of 170-172 ppm as measured through Atomic Absorption Spectroscopy. Full physicochemical parameters of AgNPGP are summarized in Table 1.

Additional characterization of AgNP-GP was performed by recording the Powder $\mathrm{X}$ ray diffraction (PXRD) pattern. As shown in Figure 4A, PXRD showed three peaks across the region of $28.5^{\circ}$ to $60.5^{\circ}$, one of which can be assigned to the Ag (lll 111$)$ peak, the main PXRD peak for Ag metal, and the other two of which match the two strongest peaks for $\mathrm{NaCl}$, which is present as a contaminant on the surfaces of the glass slides and likely entered the sample during evaporation. All peaks are shifted by $+0.7-0.8^{\circ}$ from their literature values, which indicates a sample displacement error of $+0.2 \mathrm{~cm}$. The $\mathrm{NaCl}$ peaks serve as an internal standard and clearly demonstrate the significant particle size broadening of the Ag peak. ${ }^{84}$

X-ray energy dispersive spectroscopic (EDS) evaluation further confirmed the formation of AgNP-GP. The sharp peak as seen in the silver region, in Figure $4 \mathrm{~B}$ at 3 $\mathrm{keV}$ unequivocally confirms the presence of silver nanoparticles due to the surface plasmon resonance (SPR). The occurrence of other peaks was related with the elements from the gum arabic encapsulation as well as the glass underneath, which held the sample. Figure 4B also shows an insert image corresponding to the Ag elemental mapping confirming that AgNP-GP is made of Ag in combination of the HRTEM image of the particle where the EDS map was done.

On the in vivo toxicity behavior of AgNP-GP in Daphnia similis organism, our observations indicated immobility of Daphnia similis in the acute ecotoxicity assay at $2 \mu \mathrm{g} \mathrm{L} \mathrm{L}^{-1}$ (10-15\%) of AgNP-GP. Overall, the ecotoxicity increased with increased AgNP-GP concentrations as summarized in the results section and depicted in Figure 5. Our results

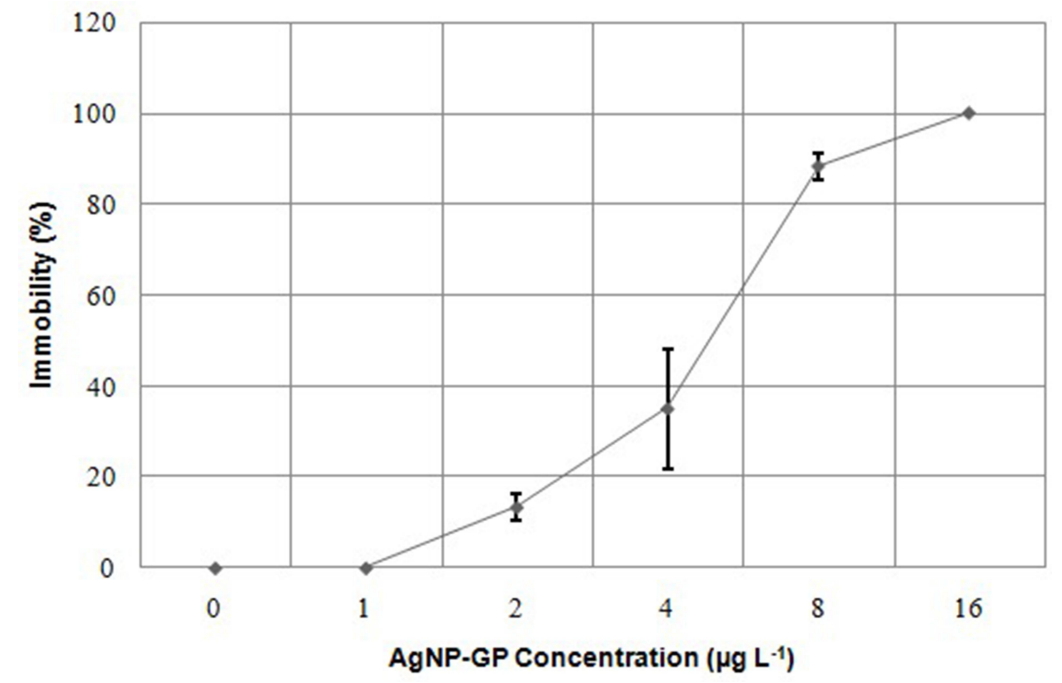

Figure 6 Immobility curve of Daphnia similis neonates as a function of AgNP-GP concentrations after 48 hours of exposure. Mean standard deviation calculated from triplicates.

Abbreviation: AgNP-GP, silver nanoparticles. 
Table $2 \mathrm{EC}_{50}$ Values, Confidence Intervals, the Mean and Standard Deviation for the Acute Ecotoxicity Assays of AgNPGP

\begin{tabular}{|l|l|l|}
\hline Assay & EC $_{\mathbf{5 0}}\left(\boldsymbol{\mu \mathrm { g } \mathrm { L } ^ { - 1 } )}\right.$ & Confidence Limit $\left(\boldsymbol{\mu g} \mathbf{L}^{-1}\right)$ \\
\hline 1 & 4.92 & $4.03-6.01$ \\
2 & 4.14 & $3.38-5.07$ \\
3 & 4.14 & $3.36-5.11$ \\
Mean & 4.40 & $3.59-5.40$ \\
Standard deviation & 0.45 & $0.38-0.53$ \\
\hline
\end{tabular}

Notes: $\mathrm{EC}_{50}$, effective concentration of AgNP-GP that causes immobility to $50 \%$ of the exposed organisms.

$\left(\mathrm{IC}_{50}=2.57 \mathrm{mg} \mathrm{L}^{-1}\right)$, as presented in this paper, corroborated well with the $\mathrm{IC}_{50}$ values reported in various publications. Leitch et $\mathrm{al}^{85}$ reported $\mathrm{IC}_{50}$ of $6.25 \mathrm{mg} \mathrm{L}^{-1}$ for spherical AgNP with 7-12 nm size using the same methodology. ${ }^{86}$
Our observations, as depicted in Figures 5 and 6 are in line with prior literature precedence. The $\mathrm{EC}_{50}$ values of AgNPs (Table 2), synthesized by different methodologies, were in the same order of magnitude as those obtained in the present study, such as $4.70 \mu \mathrm{g} \mathrm{L}^{-1} ; 6.90 \mu \mathrm{g} \mathrm{L}^{-1}$; and $13.93 \mu \mathrm{g} \mathrm{L}^{-1.31,86}$

Daphnia magna is also an experimental model widely used in acute ecotoxicity assays, but studies have shown that its sensitivity is lower than that of Daphnia similis. ${ }^{30,35,36}$ Newton et $\mathrm{al}^{37}$ obtained an $\mathrm{EC}_{50}$ value between $2.14 \mu \mathrm{g} \mathrm{L}^{-1}$ and $3.48 \mu \mathrm{g} \mathrm{L}^{-1}$ for AgNPs with approximate sizes between 7.5 and $17.9 \mathrm{~nm}$, stabilized with GP, on Daphnia magna. In this study, the sensitivity of Daphnia magna was not significantly lower than that of Daphnia similis, considering the obtained result $\left(\mathrm{EC}_{50}\right.$ of $4.40 \mu \mathrm{g} \mathrm{L}^{-1}$ for AgNP of $25 \mathrm{~nm}$ ). Volker et $\mathrm{al}^{38}$ reported acute ecotoxicity of $\mathrm{EC}_{50}$ value of 121
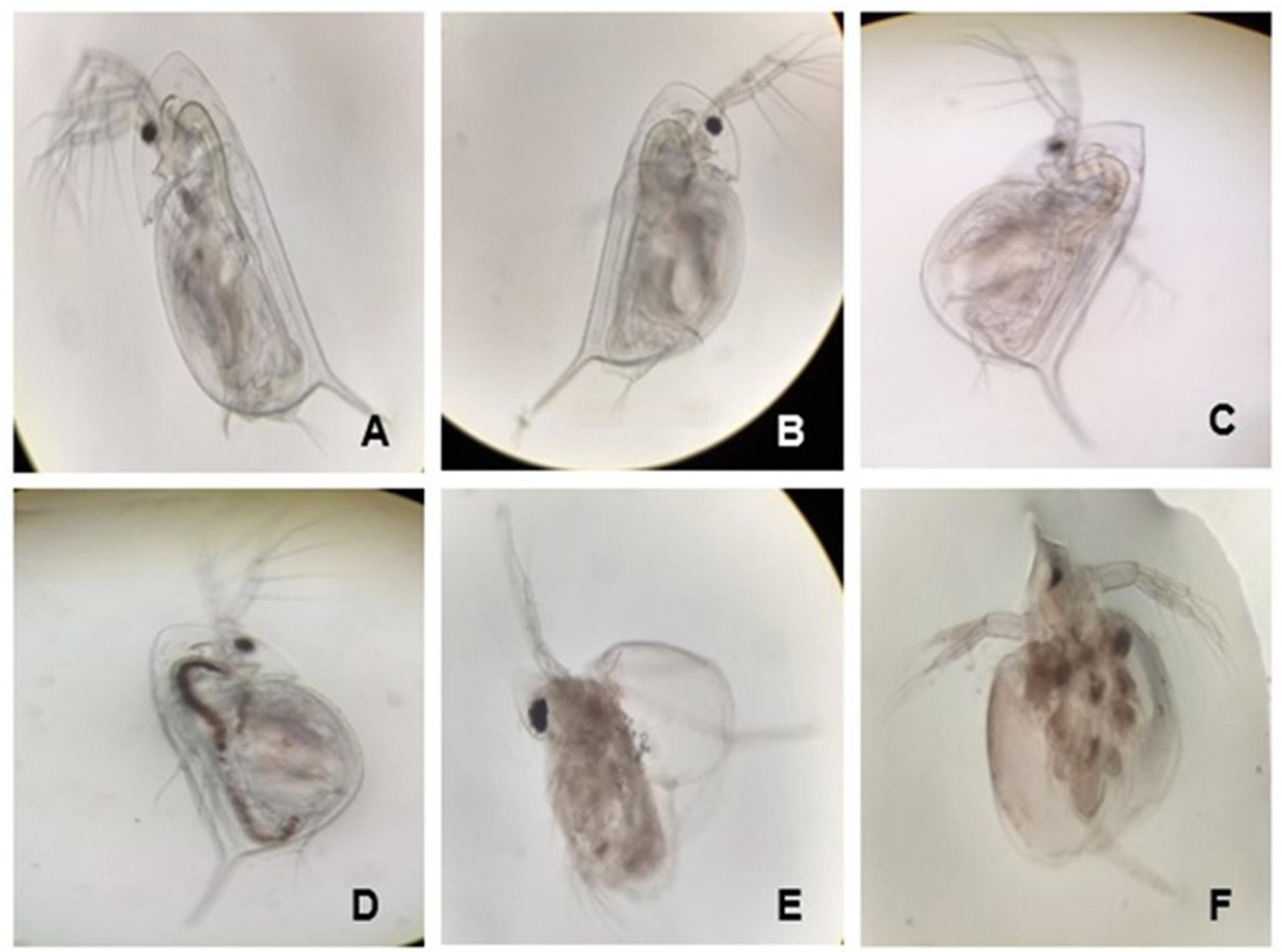

Figure 7 Daphnia similis after the acute ecotoxicity test. (A) Control in Murashige and Skoog medium (MS); Images of organisms at various AgNP-GP exposure concentrations: (B) I $\mu \mathrm{g} \mathrm{L}^{-1}$, (C) $2 \mu \mathrm{g} \mathrm{L}$, (D) $4 \mu \mathrm{g} \mathrm{L}-1$, (E) $8 \mu \mathrm{g} \mathrm{L}^{-1}$ and (F) $16 \mu \mathrm{g} \mathrm{L}^{-1}$. At I $\mu \mathrm{g} \mathrm{L}^{-1}$ and $2 \mu g \mathrm{~L}^{-1}$ AgNP-GP concentrations, the organisms showed mobility. Exposure to AgNP-GP concentrations of $4 \mu \mathrm{g} \mathrm{L}-1$ showed restricted mobility. At this concentration, dark coloration in the digestive tract, possibly due to AgNP-GP interaction, was observed. At $8 \mu \mathrm{g} \mathrm{L}^{-1}$ and $16 \mu \mathrm{g} \mathrm{\textrm {L } ^ { - 1 }} \mathrm{AgNP}-\mathrm{GP}$ concentrations, it can be inferred that the organisms became immobile and presented significant changes in their morphological structures (Magnification at 40x).

Abbreviations: AgNP-GP, silver nanoparticles; MS medium, Murashige and Skoog medium. 
Table 3 LC $_{50}$ Values, Confidence Intervals, the Mean and Standard Deviation for Acute AgNP-GP Embryotoxicity Assays

\begin{tabular}{|l|l|l|}
\hline Assay & LC $_{\mathbf{5 0}}\left(\boldsymbol{\mu g} \mathbf{L}^{-1}\right)$ & Confidence Limit $\left(\boldsymbol{\mu g ~ L}^{-1}\right)$ \\
\hline 1 & 150 & $130-170$ \\
2 & 190 & $170-220$ \\
3 & 190 & $160-210$ \\
Mean & 177 & $153-200$ \\
Standard deviation & 23.09 & $20.82-26.46$ \\
\hline
\end{tabular}

Notes: $\mathrm{LC}_{50}$, lethal concentration of AgNP-GP that causes immobility to $50 \%$ of the exposed organisms.

$\mu \mathrm{g} \mathrm{L}^{-1}$ for AgNP, with approximately $15 \mathrm{~nm}$ size stabilized with Polyvinylpyrrolidone (PVP), on Daphnia magna organism. However, Lekamge et $\mathrm{al}^{39}$ evaluated toxic effects of three different AgNP (curcumin (C-AgNP), epigallocatechin gallate (E-AgNP), and tyrosine (T-AgNP)) against Daphnia carinata. Their results showed $\mathrm{EC}_{50}$ values of AgNPs at 19.37 $\mu \mathrm{g} \mathrm{L}{ }^{-1}, 21.37 \mu \mathrm{g} \mathrm{L}{ }^{-1}$, and $49.74 \mu \mathrm{g} \mathrm{L}^{-1}$ for E-AgNP, $\mathrm{C}-\mathrm{AgNP}$, and T-AgNP, respectively. These results demonstrated that the type of stabilizing agent used contributes to the degree of toxicity of AgNP. However, it is worth noting that other factors, such as reducing agent and nanoparticle size, may also influence the overall toxicity.

Our detailed toxicity investigations using the zebrafish animal model further indicated that the lethality for Danio rerio species with exposures to AgNP-GP was concentration dependent (Figure 7 and Table 3). Our results suggest $45-68 \%$ lethality at a concentration of $156 \mu \mathrm{g} \mathrm{L}{ }^{-1}$ of AgNPGP which increased to $100 \%$ lethality when the concentration was increased to $1250 \mu \mathrm{g} \mathrm{L}^{-1}$. It may be important to consider that the AgNP-GP toxicity is caused by the $\mathrm{Ag}^{+}$ cations released from the surface of the nanoparticles. Previous studies have shown that acute toxicity to aquatic organisms is mainly attributed to the released $\mathrm{Ag}^{+.37,87-89} \mathrm{In}$ aquatic organisms, the Ag toxicity mechanism involves ionoregulatory disorder or failure associated with competitive or non-competitive inhibition of sodium or potassium ionsdependent adenosine triphosphatase $\left(\mathrm{Na}^{+}, \mathrm{K}^{+}\right.$-ATPase) activity. Silver nanoparticles appear to result in the inhibition of $\mathrm{Na}^{+}$absorption in the gills, which leads to a cascade of events that culminates in cardiac arrest and death. ${ }^{40,41}$

It is also important to note that the toxicity may be caused by AgNP itself, which is likely attributed to the generation of reactive oxygen species (ROS) resulting in oxidative stress. This mechanism of toxicity results in multiple modes of action such as mitochondrial damage, lipid peroxidation of the membrane and damage to DNA and lipids, which ultimately leads to cumulative effects of cellular apoptosis. ${ }^{32,33,42}$ We have presented, for the first time, evidence on morphological changes and acute embryotoxicity in Danio rerio - all attributed to exposure of AgNP-GP samples at various concentrations and exposure times (Figures 8 and 9). In related investigations, previously Asharani et $\mathrm{al}^{42}$ reported the effects of AgNPs exposure on embryos of Danio rerio. However, their investigations report the use of AgNPs stabilized with potato starch and bovine serum albumin (BSA), with a size of approximately $5 \mathrm{~nm}$ and $20 \mathrm{~nm}$. Results after 72 hours of exposure of $5 \mathrm{~nm}$ and $20 \mathrm{~nm} \mathrm{AgNPs,} \mathrm{revealed} \mathrm{LC}_{50}$, were $25 \mathrm{mg} \mathrm{L}^{-1}$ and $50 \mathrm{mg} \mathrm{L}^{-1}$, respectively for embryos of Danio rerio. Reports by Xin et $\mathrm{al}^{34}$ with Danio rerio embryos, showed $\mathrm{LC}_{50}$ value of $4120 \mathrm{mg} \mathrm{L}^{-1}$ after 96 hours of exposure, for

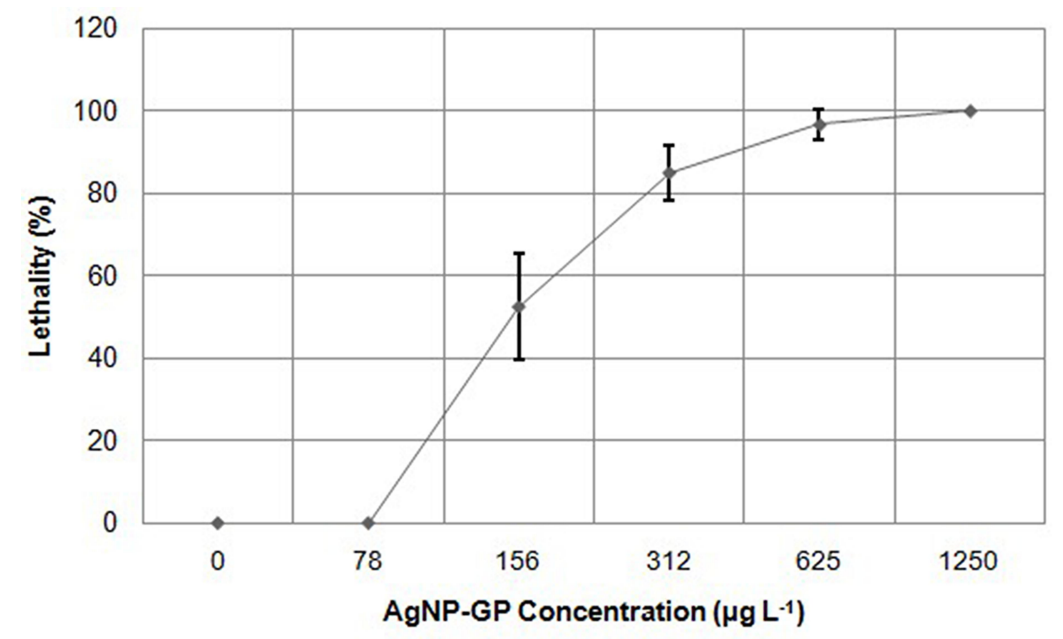

Figure 8 Lethality curve of zebrafish embryos as a function of AgNP-GP concentrations after 96 hours of exposure. Standard deviation calculated from triplicates ( $\mathrm{n}=3$ ). Abbreviation: AgNP-GP, silver nanoparticles. 


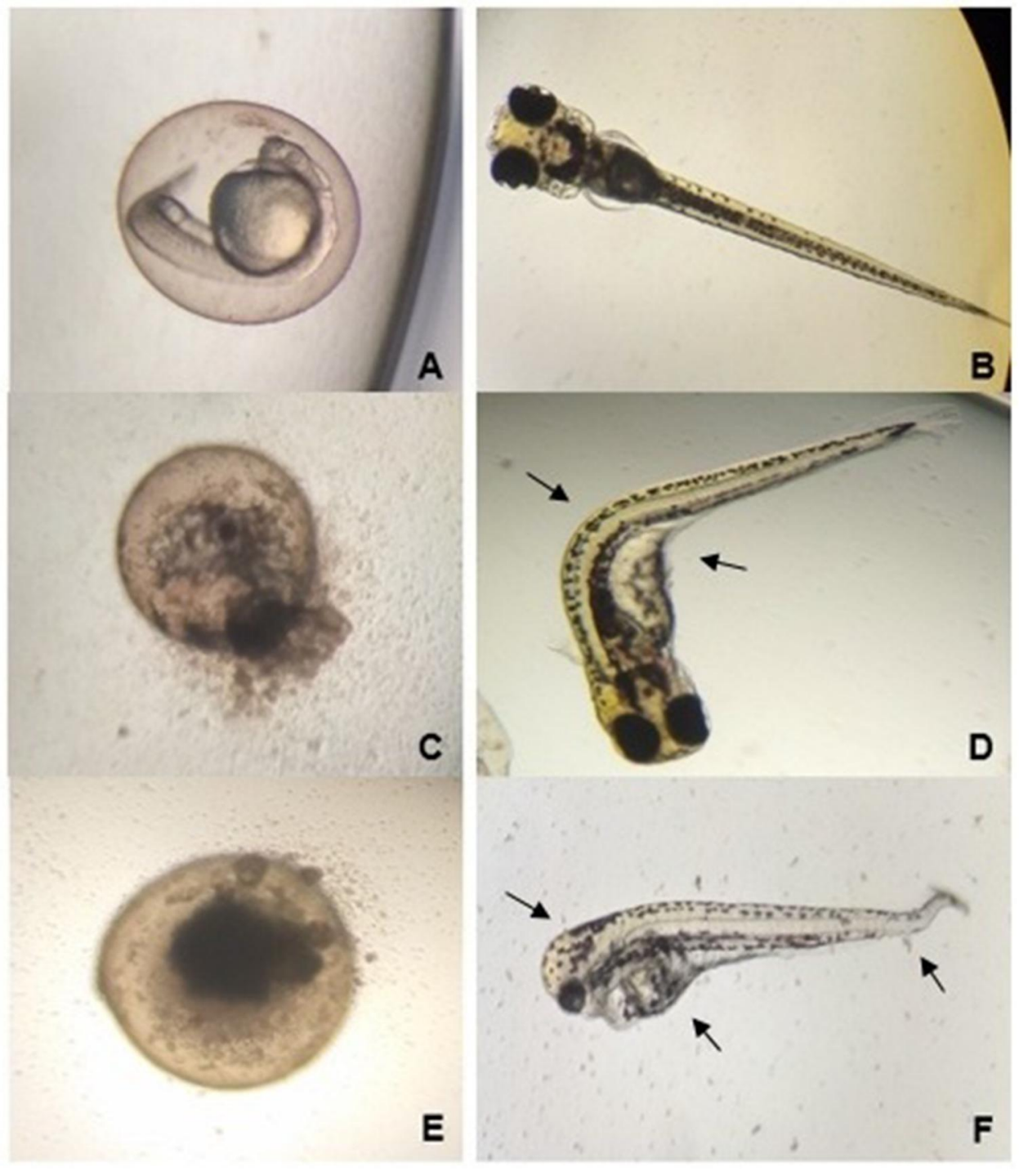

Figure 9 Images of zebrafish after acute embryotoxicity tests. (A) Control Murashige and Skoog medium (MS) 24 hpf (Magnification at 40x); (B) Control Murashige and Skoog medium (MS) $96 \mathrm{hpf}$ (Magnification at 20x); Images of organism exposures at various concentrations of AgNP-GP 96 hpf: (C) (Magnification at 40x), and (D) I56 $\mu \mathrm{g}$ $\mathrm{L}^{-1}$ (Magnification at 20x); (E) (Magnification at 40x), and (F) $625 \mu \mathrm{g} \mathrm{L}$ (Magnification at 20x). Images of control (A and B) depict normal developments. Exposed at I56 $\mu \mathrm{g}$ $\mathrm{L}^{-1}$ of AgNP-GP showed coagulated egg (C) and larvae where curvature of the spine was observed along with cardiac and vitelline edema (D). Organisms exposed to $625 \mu \mathrm{g}$ $\mathrm{L}^{-1}$ of $\mathrm{AgNP}-\mathrm{GP}$, showed coagulated egg $(\mathbf{E})$ and larvae with reduced head size, reduced body size, column curvature vertebral, cardiac and vitelline edema (F). Overall, the organisms exposed to AgNP-GP at $78 \mu \mathrm{g} \mathrm{L}{ }^{-1}$ concentration showed no lethality, however, organisms exposed to $1250 \mu \mathrm{g} \mathrm{L}^{-1}$ concentration of AgNP-GP showed $100 \%$ lethality.

Abbreviations: AgNP-GP, silver nanoparticles; MS medium, Murashige and Skoog medium.

AgNPs (with no information regarding the stabilizing agent used), with a size of approximately $3-6 \mathrm{~nm}$. Their studies also indicated $\mathrm{LC}_{50}$ of $5.909 \mathrm{mg} \mathrm{L}^{-1}$ for AgNPs with sizes in the range: $8-10 \mathrm{~nm}$. These studies suggest that the smaller the size of nanoparticles, the greater is their toxic effect. However, it is important to note that other factors, which include the type of the stabilizing agent and the reducing agents utilized in the synthetic routes, may also influence the toxicity of the AgNPs samples.
Overall, from our detailed cytotoxicity investigations, we can infer that aquatic organisms exhibit greater sensitivity to AgNP-GP samples, approximately 1000 -fold greater than the sensitivity of cells in culture. These data provide compelling evidence that knowledge of species-specific toxicity of silver nanoparticles is imperative in gaining better insights on the systematic toxicity so that antibacterial and antimicrobial applications of AgNPs can be capitalized within the health and hygiene sectors. 
Table 4 Summary of Clinical Signs of Toxicity, Mortality and Morbidity from Day 0-28

\begin{tabular}{|l|l|l|l|l|l|}
\hline $\begin{array}{l}\text { Group } \\
\text { No. }\end{array}$ & $\begin{array}{l}\text { Dose of } \\
\text { AgNP- } \\
\text { GP (mg/ } \\
\text { kg/b.w.) }\end{array}$ & Sex & $\begin{array}{l}\text { Mortalityl } \\
\text { Morbidity }\end{array}$ & $\begin{array}{l}\text { Clinical } \\
\text { Signs of } \\
\text { Toxicity }\end{array}$ & $\begin{array}{l}\text { No. } \\
\text { with } \\
\text { Clinical } \\
\text { Signs/N }\end{array}$ \\
\hline GI & 0 & M & $0 / 6$ & Normal & $6 / 6$ \\
F & $0 / 6$ & Normal & $6 / 6$ \\
\hline G2 & 5.0 & M & $0 / 6$ & Normal & $6 / 6$ \\
& & F & $0 / 6$ & Normal & $6 / 6$ \\
\hline G3 & 7.5 & M & $0 / 6$ & Normal & $6 / 6$ \\
& & F & $0 / 6$ & Normal & $6 / 6$ \\
\hline G4 & 10.0 & M & $0 / 6$ & Normal & $6 / 6$ \\
& & F & $0 / 6$ & Normal & $6 / 6$ \\
\hline
\end{tabular}

Abbreviations: b.w, body weight; GI, control group; G2, low-dose group; G3, mid-dose group; G4, high-dose group; F, female; M, male; N, number of animals.

Insights on nanoparticles toxicity can be gained from several types of in vivo toxicological investigations in animals before venturing into toxicological studies in humans. Evaluation of the toxicity of nanoparticles in multispecies organisms/animals has become a cornerstone of human safety evaluation. Toxicological studies of nanoparticles using multispecies organisms/animals make it possible in extrapolating the results from animal systems to humans. Indeed, the Environmental Protection Agency (EPA), Food and Drug Administration (FDA), and other regulatory authorities mandate investigations of experimental drugs or nanomedicine agents, derived from various nanoparticles, for evaluation of adverse effects over a wide range of doses, dosage regimens, and exposure durations before approving for human applications. Toxicity investigations in multispecies animals catalyze extrapolation of the results of toxicity and mutagenicity studies from animal systems to humans. ${ }^{90-93}$

In order to evaluate species-specific toxicity of AgNPGP, we have undertaken detailed toxicity investigations in Sprague Dawley rats. Our overarching objective was to assess the toxicity of AgNP-GP in rats so that these types of nanoparticles can be ultimately recommended with safety and risk limits of doses toward human health and environment. In this context, we reasoned that the biological activity, together with species and/or tissue specificity, should include the use of relevant species. Zebrafish may not be relevant from the viewpoint of testing the overall pharmacological activity of nanoparticles due to the absence of receptor/epitope distribution in this species. Toxicity studies in nonrelevant species may be misleading and are discouraged.
Insights into receptor/epitope distribution provide vital information on in vivo toxicity. Therefore, utility of relevant animal species, for testing the in vivo toxicity of nanoparticles, assumes a paramount role in gaining long-term toxicity information. Toxicity studies in animals are intended to ultimately translate the findings in assessing tissue crossreactivity profile in human tissues. Therefore, the choice of animal species for the evaluation of toxicity of nanoparticles (or experimental drugs) should reflect, to a greater degree, the in vivo profiles common to human beings. Therefore, we have carried out safety evaluation in Sprague Dawley rats for the complete evaluation of systemic toxicity and also for defining toxicity limits of silver nanoparticles.

In this study, the systemic toxicity of AgNP-GP in Sprague Dawley Rats was studied. Table 4 depicts full details of clinical signs of toxicity, mortality and morbidity from day 0-28. The detailed biochemical markers and histopathological results, as summarized in Table 5, unequivocally demonstrated that AgNP-GP exerted no adverse systemic toxicity effects even in the main immune system organs including the thymus and spleen. Although, the potential systemic toxicity of AgNPs remains controversial and species-specific, oral administrations of AgNPGP up to $10.0 \mathrm{mg} \mathrm{kg}^{-1}$ body weight over a 28 -day dosing regimen showed no obvious organ toxicity in both the male and female Sprague Dawley rats (Table 5).

Detailed gross pathological and histopathological analysis (Table 5), post oral administration of AgNP-GP, have conclusively revealed that, under in vivo toxicology testing conditions, gum arabic stabilized silver nanoparticles were found to be well tolerated within the $10.0 \mathrm{mg} \mathrm{kg}^{-1}$ body weight dosing range when administered orally for a period of 28 days in Sprague Dawley rats. Therefore, our results infer that the "no-observed adverse effect level (NOAEL)" limit for the AgNP-GP is $10.0 \mathrm{mg} \mathrm{kg}^{-1}$ body weight in both male and female Sprague Dawley rats.

\section{Conclusions}

In this comprehensive toxicity investigation of our silver nanoparticles (produced through green nanotechnology), we have followed globally acceptable regulatory requirements, that potential new medicines are tested in at least two animal species, for assessing safety and tolerability prior to first-inhuman (FIH) trials. Multispecies toxicity in animals have become particularly relevant in the context of testing toxicity profiles of nanomedicines and nano antibiotics or antimicrobials such as those derived from silver nanoparticles as reported in the current investigation. The results, as reported 
Table 5 Histopathology Data of Sprague Dawley Rats Treated with AgNP-GP $\left(5.0 \mathrm{mg} \mathrm{kg}{ }^{-1}-10.0\right.$ mg kg ${ }^{-1}$ Body Weight Dosing Regimen)

\begin{tabular}{|c|c|c|c|c|c|}
\hline \multirow[t]{5}{*}{ Organ Name } & \multirow{3}{*}{$\begin{array}{l}\text { Group Number } \\
\text { Dose (mg/kg/b.w.) } \\
\text { Number of animals }\end{array}$} & \multicolumn{2}{|l|}{ G I } & \multicolumn{2}{|l|}{ G4 } \\
\hline & & \multicolumn{2}{|l|}{0} & \multicolumn{2}{|c|}{10.0} \\
\hline & & 6 & 6 & 6 & 6 \\
\hline & Sex & $\mathbf{M}$ & $\mathbf{F}$ & $\mathbf{M}$ & $\mathbf{F}$ \\
\hline & Histopathology indings & & & & \\
\hline \multirow[t]{2}{*}{ Lungs } & Examined & 6 & 6 & 6 & 6 \\
\hline & Infiltrate, cellular minimal & 2 & 2 & 1 & 2 \\
\hline \multirow[t]{2}{*}{ Liver } & Examined & 6 & 6 & 6 & 6 \\
\hline & $\begin{array}{l}\text { Vacuolation, cytoplasmic, hepatocytes, focal } \\
\text { minimal }\end{array}$ & 0 & 1 & 0 & I \\
\hline \multirow[t]{3}{*}{ Adrenals } & Examined & 6 & 6 & 6 & 6 \\
\hline & Accessory adrenocortical nodules, present & 0 & 0 & 0 & $\mathrm{I}$ \\
\hline & Vacuolization, cytoplasmic, cortex minimal & 1 & 0 & 1 & 0 \\
\hline \multirow[t]{2}{*}{ Uterus with cervix } & Examined & - & 6 & - & 6 \\
\hline & Dilation, lumen, uterine horn, present & NA & 1 & NA & 0 \\
\hline $\begin{array}{l}\text { Skin with mammary gland, mesenteric lymph node, } \\
\text { trachea, esophagus, thyroid and parathyroid, thymus, } \\
\text { heart, aorta, eyes, brain, stomach, duodenum, } \\
\text { jejunum, ileum, Peyer's patches, cecum, colon, rectum, } \\
\text { spleen, kidneys, urinary bladder, testes, epididymitis, } \\
\text { male sex glands, ovaries, vagina, skeletal muscle, } \\
\text { pancreas, pituitary gland, salivary glands and spinal } \\
\text { cord }\end{array}$ & \multicolumn{5}{|l|}{ No noticeable changes observed } \\
\hline
\end{tabular}

Notes: Figures examined indicate number of slides examined microscopically in the particular group; other figures indicate number of findings per organ in the particular group.

Abbreviations: GI, control group; G4, high-dose group; F, female; M, male; NA, not applicable.

herein, demonstrate that our silver nanoparticles exhibited toxicity in a zebrafish animal model while no toxicity was found in the Sprague Dawley rat model-thus exemplifying the importance of the use of two species (a rodent and a nonrodent) for toxicological assessment of nanomedicines. Our investigations unequivocally show that silver nanoparticles stabilized through gum arabic protein (AgNP-GP) can be safely utilized as broad-spectrum antibiotics in a range of consumer products including as antimicrobial (such as antibacterial, antifungal and antiviral) agents both for in vitro and in vivo product development applications.

\section{Acknowledgments}

The authors thank the Brazilian National Council for Scientific and Technological Development (CNPq) for partial financial support through scholarships. This project received partial financial support by Dhanvantari Nano Ayushadi Private Limited (DNA). KVK thanks various members of his research group, over the years, who are also authors in cited references in this publication for their seminal contributions at various stages of this work as listed in various cited publications. Logistical support from the Institute of Green Nanotechnology, University of Missouri is gratefully acknowledged.

\section{Disclosure}

DarshaKumar Dhurvas Mohandoss, Rashmi DarshaKumar Dhurvas, and Mohanavelu Nappinnai are employees of Dhanvantari Nano Ayushadi Pvt Ltd. The authors report no other potential conflicts of interest for this work. 


\section{References}

1. Vance ME, Kuiken T, Vejerano EP, et al. Nanotechnology in the real world: redeveloping the nanomaterial consumer products inventory. Beilstein J Nanotechnol. 2015;6:1769-1780. doi:10.3762/bjnano.6.181

2. Heath JR. Nanotechnologies for biomedical science and translational medicine. Proc Natl Acad Sci U S A. 2015;112(47):14436-14443. doi:10.1073/pnas.1515202112

3. Paradise J. Regulating nanomedicine at the food and drug administration. AMA J Ethics. 2019;21(4):347-355. doi:10.1001/ amajethics.2019.347

4. Katti KV. Renaissance of nuclear medicine through green nanotechnology: functionalized radioactive gold nanoparticles in cancer therapy - my journey from chemistry to saving human lives. $J$ Radioanal Nucl Chem. 2016;309(1):5-14. doi:10.1007/s10967-016-4888-0

5. Roco MC. The long view of nanotechnology development: the national nanotechnology initiative at 10 years. $J$ Nanopart Res. 2011;13(2):427-445. doi:10.1007/s11051-010-0192-z

6. Corrie SR, Thurecht KJ. Nano-bio interactions: guiding the development of nanoparticle therapeutics, diagnostics, and imaging agents. Pharm Res. 2016;33(10):2311-2313. doi:10.1007/s11095-016-2009-y

7. Maynard AD, Aitken RJ. "Safe handling of nanotechnology" ten years on. Nat Nanotechnol. 2016;11(12):998-1000. doi:10.1038/ nnano. 2016.270

8. He X, Hwang H-M. Nanotechnology in food science: functionality, applicability, and safety assessment. J Food Drug Anal. 2016;24 (4):671-681. doi:10.1016/j.jfda.2016.06.001

9. Di Sia P. Nanotechnology among innovation, health and risks. Procedia Soc Behav Sci. 2017;237:1076-1080. doi:10.1016/j.sbspro.2017.02.158

10. Li Q, Luo T, Taylor MG, et al. Molecular " surgery " on a 23-goldatom nanoparticle. Sci $A d v$. 2017;3(5):e1603193. doi:10.1126/ sciadv. 1603193

11. Pruitt TR, Hochella MF, Hull MS, et al. Chapter 8 - NanoEarth (National Center for Earth and Environmental Nanotechnology Infrastructure). In: Hull MS, Bowman DMBT-NEH, Third ES, editors. Micro and Nano Technologies. William Andrew Publishing; 2018:169-192. doi:10.1016/B978-0-12-813588-4.00008-7

12. Kargozar S, Mozafari M. Nanotechnology and nanomedicine: start small, think big. Mater Today Proc. 2018;5(7, Part 3):15492-15500. doi:10.1016/j.matpr.2018.04.155

13. Medina-Pérez G, Fernández-Luqueño F, Vazquez-Nuñez E, et al. Remediating polluted soils using nanotechnologies: environmental benefits and risks. Polish J Environ Stud. 2019;28(3):1013-1030. doi:10.15244/pjoes/87099

14. de Souza GD, Rodrigues MA, Silva PP, Guerra W. Silver: brief history, properties and applications | prata: breve histórico, propriedades e aplicações. Educ Quim. 2013;24(1):14-16.

15. Zhang X-F, Liu Z-G, Shen W, Gurunathan S. Silver nanoparticles: synthesis, characterization, properties, applications, and therapeutic approaches. Int J Mol Sci. 2016;17(9):1534. doi:10.3390/ijms 17091534

16. Wang L, Hu C, Shao L. The antimicrobial activity of nanoparticles: present situation and prospects for the future. Int $J$ Nanomedicine. 2017;12:1227-1249. doi:10.2147/IJN.S121956

17. Vijayan R, Joseph S, Mathew B. Indigofera tinctoria leaf extract mediated green synthesis of silver and gold nanoparticles and assessment of their anticancer, antimicrobial, antioxidant and catalytic properties. Artif Cells Nanomed Biotechnol. 2018;46(4):861-871. doi:10.1080/21691401.2017.1345930

18. Sadasivuni KK, Rattan S, Waseem S, Bramhe SK, Kondawar SB, Ghosh S, Das AP, Chakraborty PK, Adhikari J, Saha P, Mazumdar P. Silver nanoparticles and it's polymer nanocomposites-Synthesis, optimization, biomedical usage, and its various applications. Polymer nanocomposites in biomedical engineering (page 331-373). In: Sadasivuni KK, Ponnamma D, Rajan M, Ahmed B, Al-Maadeed MASA, editors. Springer International Publishing; 2019:C1. doi:10.1007/978-3-030-04741-2_11
19. Thiagamani SMK, Rajini N, Siengchin S, Varada Rajulu A, Hariram N, Ayrilmis N. Influence of silver nanoparticles on the mechanical, thermal and antimicrobial properties of cellulose-based hybrid nanocomposites. Compos Part B Eng. 2019;165:516-525. doi:10.1016/j.compositesb.2019.02.006

20. Adlhart C, Verran J, Azevedo NF, et al. Surface modifications for antimicrobial effects in the healthcare setting: a critical overview. J Hosp Infect. 2018;99(3):239-249. doi:10.1016/j.jhin.2018.01.018

21. Khatoon Z, McTiernan CD, Suuronen EJ, Mah T-F, Alarcon EI. Bacterial biofilm formation on implantable devices and approaches to its treatment and prevention. Heliyon. 2018;4(12): $\mathrm{e} 01067$. doi:10.1016/j.heliyon.2018.e01067

22. Mao BH, Chen ZY, Wang YJ, Yan SJ. Silver nanoparticles have lethal and sublethal adverse effects on development and longevity by inducing ROS-mediated stress responses. Sci Rep. 2018;8 (1):1-16. doi:10.1038/s41598-018-20728-Z

23. Sim W, Barnard RT, Blaskovich MAT, Ziora ZM. Antimicrobial silver in medicinal and consumer applications: a patent review of the past decade (2007-2017). Antibiot. 2018;7(4):93. doi:10.3390/antibiotics7040093

24. Song W, Ge S. Application of antimicrobial nanoparticles in dentistry. Molecules. 2019;24(6):1033. doi:10.3390/molecules24061033

25. Suzuki TYU, Gallego J, Assunção WG, Briso ALF, Dos Santos PH. Influence of silver nanoparticle solution on the mechanical properties of resin cements and intrarradicular dentin. PLoS One. 2019;14(6): e0217750-e0217750. doi:10.1371/journal.pone.0217750

26. Miller JC, Serrato R, Represas-Cardenas JM, Kundahl G. The Handbook of Nanotechnology: Business, Policy, and Intellectual Property Law; New Jersey: John Wiley \& Sons, Inc., 2005. doi:10.1016/j.patrec.2005.01.006

27. Noguez C. Surface plasmons on metal nanoparticles: the influence of shape and physical environment. J Phys Chem C. 2007;111 (10):3806-3819. doi:10.1021/jp066539m

28. Nogueira PFM, Paino IMM, Zucolotto V. Nanosilver: Properties, applications and impacts on public health and the environment. Health Surveillance in Debate. 2013;1(4):59-71. doi:10.3395/vd.v1i4.88pt

29. Bertoletti E, Bertoletti E. Aquatic Ecotoxicology: Principles and applications. 2nd ed. Zagatto PA, Bertoletti E, ed. São Paulo: Rima. 2008. 472 p.

30. Costa CR, Olivi P, Botta CMR, Espindola ELG. Toxicity in aquatic environments: discussion and evaluation methods. . New Chemistry. 2008;31(7):1820-1830. doi:10.1590/S0100-40422008000700038

31. Maziero JDS, Rogero SO, Alemany A. Ecotoxicological study of silver nanoparticle on Daphnia similis. $J$ Health Sci Inst. 2016;34:133-139.

32. Griffitt RJ, Luo J, Gao J, Bonzongo J-C, Barber DS. Effects of particle composition and species on toxicity of metallic nanomaterials in aquatic organisms. Environ Toxicol Chem. 2008;27(9):1972-1978. doi: $10.1897 / 08-002.1$

33. Choi JE, Kim S, Ahn JH, et al. Induction of oxidative stress and apoptosis by silver nanoparticles in the liver of adult zebrafish. Aquat Toxicol. 2010;100(2):151-159. doi:10.1016/j.aquatox.2009.12.012

34. Xin Q, Rotchell JM, Cheng J, Yi J, Zhang Q. Silver nanoparticles affect the neural development of zebrafish embryos. $J$ Appl Toxicol. 2015;35(12):1481-1492. doi:10.1002/jat.3164

35. Beatrici AC, Arenzon A, Coimbra NJ, Raya-Rodriguez MTM. Fertility and sensitivity of Daphnia similis and Daphnia magna submitted to different cultures. J Braz Soc Ecotoxicol. 2006;1 (2):123-126. doi:10.5132/jbse.2006.02.006

36. Li T, Albee B, Alemayehu M, et al. Comparative toxicity study of Ag, $\mathrm{Au}$, and $\mathrm{Ag}-\mathrm{Au}$ bimetallic nanoparticles on Daphnia magna. Anal Bioanal Chem. 2010;398(2):689-700. doi:10.1007/s00216-010-3915-1

37. Newton KM, Puppala HL, Kitchens CL, Colvin VL, Klaine SJ. Silver nanoparticle toxicity to Daphnia magna is a function of dissolved silver concentration. Environ Toxicol Chem. 2013;32(10):2356-2364. doi:10.1002/etc. 2300 
38. Völker C, Boedicker C, Daubenthaler J, Oetken M, Oehlmann J. Comparative toxicity assessment of nanosilver on three Daphnia species in acute, chronic and multi-generation experiments. PLoS One. 2013;8(10):e75026-e75026. doi:10.1371/journal.pone.0075026

39. Lekamge S, Miranda AF, Ball AS, Shukla R, Nugegoda D. The toxicity of coated silver nanoparticles to Daphnia carinata and trophic transfer from alga Raphidocelis subcapitata. PLoS One. 2019;14(4): e0214398. doi:10.1371/journal.pone.0214398

40. Hogstrand C, Wood CM. Toward a better understanding of the bioavailability, physiology, and toxicity of silver in fish: implications for water quality criteria. Environ Toxicol Chem. 1998;17 (4):547-561. doi:10.1002/etc.5620170405

41. Bianchini A, Wood CM. Mechanism of acute silver toxicity in Daphnia magna. Environ Toxicol Chem. 2003;22(6):1361-1367. doi:10.1002/etc.5620220624

42. Asharani PV, Lian Wu Y, Gong Z, Valiyaveettil S. Toxicity of silver nanoparticles in zebrafish models. Nanotechnology. 2008;19 (25):255102. doi:10.1088/0957-4484/19/25/255102

43. Lawrence C. The husbandry of zebrafish (Danio rerio): a review. Aquaculture. 2007;269(1-4):1-20. doi:10.1016/j.aquaculture.2007.04. 077

44. Chakraborty C, Sharma AR, Sharma G, Lee -S-S. Zebrafish: a complete animal model to enumerate the nanoparticle toxicity. $J$ Nanobiotechnology. 2016;14(1):65. doi:10.1186/s12951-0160217-6

45. Spence R, Smith C. Male territoriality mediates density and sex ratio effects on oviposition in the zebrafish, Danio rerio. Anim Behav. 2005;69(6):1317-1323. doi:10.1016/j.anbehav.2004.10.010

46. Boudreau MD, Imam MS, Paredes AM, et al. Differential effects of silver nanoparticles and silver ions on tissue accumulation, distribution, and toxicity in the sprague dawley rat following daily oral gavage administration for 13 weeks. Toxicol Sci. 2016;150 (1):131-160. doi:10.1093/toxsci/kfv318

47. Barut BA, Zon LI. Realizing the potential of zebrafish as a model for human disease. Physiol Genomics. 2000;2(2):49-51. doi:10.1152/ physiolgenomics.2000.2.2.49

48. Shin JT, Priest JR, Ovcharenko I, et al. Human-zebrafish non-coding conserved elements act in vivo to regulate transcription. Nucleic Acids Res. 2005;33(17):5437-5445. doi:10.1093/nar/gki853

49. Teame T, Zhang Z, Ran C, et al. The use of zebrafish (Danio rerio) as biomedical models. Anim Front. 2019;9(3):68-77. doi:10.1093/af/vfz020

50. Raghuraman KKVK (12) United States Patent (10) Patent No US 9,005,663 B2;2015:2(12).

51. Berning DE, Katti KV, Barnes CL, Volkert WA. Chemical and biomedical motifs of the reactions of hydroxymethylphosphines with amines, amino acids, and model peptides. J Am Chem Soc. 1999;121(8):1658-1664. doi:10.1021/ja9827604

52. Raghuraman K, Katti KK, Barbour LJ, Pillarsetty N, Barnes CL, Katti KV. Characterization of supramolecular $(\mathrm{H} 2 \mathrm{O}) 18$ water morphology and water-methanol $(\mathrm{H} 2 \mathrm{O}) 15(\mathrm{CH} 3 \mathrm{OH}) 3$ clusters in a novel phosphorus functionalized trimeric amino acid host. $J$ Am Chem Soc. 2003;125(23):6955-6961. doi:10.1021/ja034682c

53. Katti KV, Gali H, Smith CJ, Berning DE. Design and development of functionalized water-soluble phosphines: catalytic and biomedical implications. Acc Chem Res. 1999;32(1):9-17. doi:10.1021/ ar9800082

54. Kattesh KV, Douglas BE, Wynn VA, Alan KR, Robert C. United States Patent No. US005,948,386 (19). 1999;(19).

55. Apex T, Gui T. APEX3 sets new standards for usability and performance. Bruker-AXS. 2018;8:38.

56. ABNT NBR 15088. Aquatic ecotoxicology - Acute toxcity - Test method with fish (Cyprinidae); Brazilian Association of Technical Standards, 2011.

57. Ali BH, Ziada A, Blunden G. Biological effects of gum arabic: A review of some recent research. Food Chem Toxicol. 2009;47 (1):1-8. doi:10.1016/j.fct.2008.07.001
58. Hamilton MA, Russo RC, Thurston RV. Trimmed Spearman-Karber method for estimating median lethal concentrations in toxicity bioassays. Environ Sci Technol. 1977;11(7):714-719. doi:10.1021/ es60130a004

59. Busquet F, Halder BT. OECD guidelines for the testing of chemicals 236 - fish embryo acute toxicity (FET) test. OECD Obs; July 26, 2013.

60. Chanda N, Kattumuri V, Shukla R, et al. Bombesin functionalized gold nanoparticles show in vitro and in vivo cancer receptor specificity. Proc Natl Acad Sci. 2010;107(19):8760-8765. doi:10.1073/pnas.1002143107

61. Boote E, Fent G, Kattumuri V, et al. Gold nanoparticle contrast in a phantom and juvenile swine: models for molecular imaging of human organs using X-ray computed tomography. Acad Radiol. 2010;17(4):410-417. doi:10.1016/j.acra.2010.01.006

62. Katti KK, Kattumuri V, Bhaskaran S, Katti KV, Kannan R. Facile and general method for synthesis of sugar-coated gold nanoparticles. Int J Green Nanotechnol Biomed. 2009;1(1):B53-B59. doi:10.1080/ 19430850902983848

63. Katti K, Chanda N, Shukla R, et al. Green nanotechnology from cumin phytochemicals: generation of biocompatible gold nanoparticles. Int J Green Nanotechnol Biomed. 2009;1(1):B39B52. doi:10.1080/19430850902931599

64. Nune SK, Chanda N, Shukla R, et al. Green nanotechnology from tea: phytochemicals in tea as building blocks for production of biocompatible gold nanoparticles. $J$ Mater Chem. 2009;19 (19):2912-2920. doi:10.1039/b822015h

65. Shukla R, Nune SK, Chanda N, et al. Soybeans as a phytochemical reservoir for the production and stabilization of biocompatible gold nanoparticles. Small. 2008;4(9):1425-1436. doi:10.1002/ smll.200800525

66. Kattumuri V, Katti K, Bhaskaran S, et al. Gum Arabic as a phytochemical construct for the stabilization of gold nanoparticles: in vivo pharmacokinetics and X-ray-contrast-imaging studies. Small. 2007;3(2):333-341. doi:10.1002/smll.200600427

67. Owen A, Dufès C, Moscatelli D, et al. The application of nanotechnology in medicine: treatment and diagnostics. Nanomedicine. 2014;9(9):1291-1294. doi:10.2217/nnm.14.93

68. Katti K, Shukla R, Chanda R, et al. SP-0593 green nanotechnology generates gold nanoparticles (AuNP-EGCG): implications in prostate tumor therapy. Radiother Oncol. 2012;103:S236-S237. doi:10.1016/ S0167-8140(12)70931-3

69. Kannan R, Zambre A, Chanda N, et al. Functionalized radioactive gold nanoparticles in tumor therapy. Wiley Interdiscip Rev Nanomed Nanobiotechnol. 2012;4(1):42-51. doi:10.1002/wnan.161

70. Chanda N, Shukla R, Zambre A, et al. An effective strategy for the synthesis of biocompatible gold nanoparticles using cinnamon phytochemicals for phantom CT imaging and photoacoustic detection of cancerous cells. Pharm Res. 2011;28(2):279-291. doi:10.1007/ s11095-010-0276-6

71. K V K, Khoobchandani M, Thipe VC, et al. Prostate tumor therapy advances in nuclear medicine: green nanotechnology toward the design of tumor specific radioactive gold nanoparticles. J Radioanal Nucl Chem. 2018;318(3):1737-1747. doi:10.1007/ s10967-018-6320-4

72. Chanda N, Upendran A, Boote EJ, et al. Gold nanoparticle based $\mathrm{X}$-ray contrast agent for tumor imaging in mice and dog: a potential nano-platform for computer tomography theranostics. $J$ Biomed Nanotechnol. 2014;10(3):383-392. doi:10.1166/jbn.2014.1725

73. Afrasiabi Z, Shukla R, Chanda N, et al. Nanoscale sensor design via in situ labeling of gold nanoparticles onto protein scaffolds. $J$ Nanosci Nanotechnol. 2010;10(2):719-725. doi:10.1166/ jnn.2010.1906

74. Kannan R, Rahing V, Cutler C, et al. Nanocompatible chemistry toward fabrication of target-specific gold nanoparticles. J Am Chem Soc. 2006;128(35):11342-11343. doi:10.1021/ja063280c 
75. Chanda N, Kan P, Watkinson LD, et al. Radioactive gold nanoparticles in cancer therapy: therapeutic efficacy studies of GA-198AuNP nanoconstruct in prostate tumor-bearing mice. Nanomed Nanotechnol Biol Med. 2010;6(2):201-209. doi:10.1016/j. nano.2009.11.001

76. Fent GM, Casteel SW, Kim DY, et al. Biodistribution of maltose and gum arabic hybrid gold nanoparticles after intravenous injection in juvenile swine. Nanomed Nanotechnol Biol Med. 2009;5(2):128-135. doi:10.1016/j.nano.2009.01.007

77. Gamal-Eldeen AM, Moustafa D, El-Daly SM, et al. Photothermal therapy mediated by gum Arabic-conjugated gold nanoparticles suppresses liver preneoplastic lesions in mice. J Photochem Photobiol B Biol. 2016;163:47-56. doi:10.1016/j.jphotobiol.2016.08.009

78. Shukla R, Chanda N, Zambre A, et al. Laminin receptor specific therapeutic gold nanoparticles (198AuNP-EGCg) show efficacy in treating prostate cancer. Proc Natl Acad Sci U S A. 2012;109 (31):12426-12431. doi:10.1073/pnas.1121174109

79. Sleightholm L, Zambre A, Chanda N, Afrasiabi Z, Katti K, Kannan R. New nanomedicine approaches using gold-thioguanine nanoconjugates as metallo-ligands. Inorganica Chim Acta. 2011;372 (1):333-339. doi:10.1016/j.ica.2011.01.065

80. Katti K, Kannan R, Katti K, Pillarsetty N, Barnes C. New phosphorus chemistry leads to unnatural aminoacid trimers. Phosphorus Sulfur Silicon Relat Elem. 2002;177:1587-1589. doi:10.1080/10426500212214

81. Aflori M, Butnaru M, Tihauan B-M, Doroftei F. Eco-friendly method for tailoring biocompatible and antimicrobial surfaces of poly-L-lactic acid. Nanomater. 2019;9(3):428. doi:10.3390/ nano9030428

82. Badi'ah HI, Seedeh F, Supriyanto G, Zaidan AH. Synthesis of silver nanoparticles and the development in analysis method. IOP Conf Ser Earth Environ Sci. 2019;217:12005. doi:10.1088/1755-1315/217/1/ 012005

83. Bélteky P, Rónavári A, Igaz N, et al. Silver nanoparticles: aggregation behavior in biorelevant conditions and its impact on biological activity. Int J Nanomedicine. 2019;14:667-687. doi:10.2147/IJN. S185965

84. Project RRUFF. Silver R070416. RRUFF ID no. R070416; 2019. Available from: https://rruff.info/silver/display=default/R070416. Accessed July 16, 2020.
85. Leitch IOW, Kucukcelebi A, Robson MC. Inhibition of wound contraction by topical antimicrobials. Aust $N Z J$ Surg. 1993;63 (4):289-293. doi:10.1111/j.1445-2197.1993.tb00385.x

86. Rogero SO, Quintino MTA, Almeida PR, Dias RR, Lugão AB, Rogero JR. Toxicity of silver nanoparticle (AgNP): comparative study between AgNP suspensions obtained by different methods. 4th Edition of Work Biomaterials, Eng Tissues and Artif Organs; 2015. Available from: http://repositorio.ipen.br:8080/xmlui/bitstream/handle/ 123456789/26162/22149.pdf?sequence=1\&isAllowed=y. Accessed September 1, 2020.

87. Kittler S, Greulich C, Diendorf J, Köller M, Epple M. Toxicity of silver nanoparticles increases during storage because of slow dissolution under release of silver ions. Chem Mater. 2010;22 (16):4548-4554. doi:10.1021/cm100023p

88. Wal R. Nanoparticulate silver: evaluation of potential application and the risk associated with water disinfection in comparison with conventional chlorination systems [master's dissertation]. São Paulo: Technological Research Institute; 2010.

89. Mathias FT, Romano MA, Romano RM. Evaluation of toxicological effects and environmental of nanoparticles of salts of silver / assessment of toxic and environmental effects of silver salt nanoparticles. Rev. Science. Pharm. Basic App. 2014;35(2):187-193.

90. Butler WH. Species Specificity of Organ Toxicity. In: Degen GH, Seiler JP, Bentley P, editors. Toxicology in Transition. Archives of Toxicology (Supplement), vol 17, Berlin, Heidelberg: Springer; 1995:351-356. doi:10.1007/978-3-642-79451-3_30

91. Awkerman JA, Raimondo S, Jackson CR, Barron MG. Augmenting aquatic species sensitivity distributions with interspecies toxicity estimation models. Environ Toxicol Chem. 2014;33(3):688-695. doi: $10.1002 /$ etc. 2456

92. Boverhof DR, Burgoon LD, Tashiro C, et al. Comparative toxicogenomic analysis of the hepatotoxic effects of TCDD in sprague dawley rats and C57BL/6 mice. Toxicol Sci. 2006;94(2):398-416. doi:10.1093/toxsci/kfl100

93. Court MH. Feline drug metabolism and disposition: pharmacokinetic evidence for species differences and molecular mechanisms. Vet Clin North Am Small Anim Pract. 2013;43(5):1039-1054. doi:10.1016/j. cvsm.2013.05.002
International Journal of Nanomedicine

\section{Publish your work in this journal}

The International Journal of Nanomedicine is an international, peerreviewed journal focusing on the application of nanotechnology in diagnostics, therapeutics, and drug delivery systems throughout the biomedical field. This journal is indexed on PubMed Central, MedLine, CAS, SciSearch ${ }^{\circledR}$, Current Contents ${ }^{\mathbb{R}} /$ Clinical Medicine, $^{-}$

\section{Dovepress}

Journal Citation Reports/Science Edition, EMBase, Scopus and the Elsevier Bibliographic databases. The manuscript management system is completely online and includes a very quick and fair peer-review system, which is all easy to use. Visit http://www.dovepress.com/ testimonials.php to read real quotes from published authors. 